\title{
Diálogo em campanha: uma análise das estratégias comunicativas de confronto na eleição presidencial brasileira de 2014
}

\author{
Marcia Dias $^{1}$ (D)
}

\begin{abstract}
Este artigo pretende identificar a ocorrência do diálogo, sua natureza e contribuição para o esclarecimento das propostas eleitorais das três principais candidaturas em disputa nas eleições presidenciais de 2014: Dilma Rousseff (PT), Aécio Neves (PSDB) e Marina Silva (PSB). A fonte primordial de informações foi o Horário Gratuito de Propaganda Eleitoral - HGPE (bloco e spots) veiculado durante os dois turnos das eleições. O primeiro objetivo foi elaborar uma análise quantitativa da ocorrência do diálogo direto entre as candidaturas. O segundo objetivo foi qualificar a natureza desse diálogo, classificando-o em três categorias: desconstrução da imagem pessoal, desconstrução da imagem política e crítica ao projeto político defendido pelo adversário. Tal classificação permitiu avaliar em que medida o diálogo entre os candidatos possibilitou discernir com maior ou menor clareza os contornos políticoideológicos entre os projetos governamentais em disputa. Conclui-se que a ocorrência do diálogo entre os presidenciáveis em 2014 foi potencializada pelo aumento súbito da competitividade da campanha.
\end{abstract}

Palavras-chave: campanha eleitoral; diálogo; democracia; eleições

\section{Introdução}

A eleição presidencial brasileira de 2014 revigorou o ânimo ideológico, especialmente entre os eleitores, mas também entre as candidaturas. O radicalismo tomou conta do debate público e intensificou-se durante o segundo turno. Conforme Brugnago e Chaia (2015), houve uma intensa polarização assimétrica entre esquerda e direita, ocasionada pela radicalização dessa última. A internet - em particular as redes sociais, mas também os blogs políticos - tornou-se palco para a expressão das mais contundentes opiniões sobre os principais candidatos em disputa: amizades se desfizeram, famílias se dividiram, convicções ideológicas adormecidas vieram à tona.

Partindo da constatação de estudos anteriores de que o ambiente informacional em campanhas tradicionais é dominado pelos dois maiores partidos em disputa, sendo considerada a comunicação de uma terceira força geralmente insignificante (Xenos e Foot,

\footnotetext{
${ }^{1}$ Universidade Federal do Estado do Rio de Janeiro, Departamento de Ciência Política. Rio de Janeiro (RJ), Brasil. E-mail: <marcia.dias@unirio.br>.
} 
2005), a pesquisa que deu origem a este artigo tinha como objetivo analisar as estratégias comunicativas das duas principais candidaturas durante o segundo turno, PT e PSDB, em virtude do fato de que esses dois partidos polarizaram as disputas presidenciais no Brasil entre 1994 e 2014. Essa é a primeira justificativa para essa delimitação do objeto. A segunda justificativa residiria na intensificação sem precedentes, ocorrida no segundo turno, da disputa político-ideológica entre as candidaturas. É durante o segundo turno das eleições que, em geral, aumenta a incidência de diálogo entre as candidaturas. A principal explicação para esse fenômeno estaria na polarização que ocorre na segunda etapa do confronto e induz as candidaturas a referirem-se mutuamente. Entretanto, durante o processo de discussão e análise de dados, tornou-se inevitável incorporar tanto a campanha da terceira força, Marina Silva (PSB), e consequentemente a análise do primeiro turno das eleições, quanto a análise dos spots de campanha em ambos os turnos. Supostamente, o diálogo das principais candidaturas com Marina, especialmente a do PT, poderia conter um estilo mais agressivo. Além disso, em tese, os spots conteriam mais propaganda negativa entre os adversários, ampliando significativamente o material dialógico a ser analisado.

Neste artigo, portanto, pretendo identificar a ocorrência do diálogo, sua natureza e contribuição para o esclarecimento das propostas eleitorais das três principais candidaturas durante o primeiro turno das eleições presidenciais de 2014. O foco central, entretanto, permanece sendo a verificação da qualidade do diálogo entre as duas principais forças em campanha: Dilma Rousseff (PT) e Aécio Neves (PSDB), cuja disputa se intensificou durante o segundo turno das eleições. A fonte primordial de informações será o HGPE, em bloco e spots. Em primeiro lugar, o objetivo é elaborar uma análise quantitativa da ocorrência do diálogo direto entre as candidaturas, identificando o quanto cada candidato utilizou esse recurso comunicativo. A condição mínima para a identificação do diálogo em campanha é mencionar o oponente e/ou seu histórico pessoal ou político, esperando que ele responda a essa menção ou que a ignore, nesse caso correndo o risco de prevalecer a opinião do adversário como sendo a verdadeira. A decisão de dialogar é uma escolha estratégica que depende da percepção de vantagens relativas que podem ser obtidas pela candidatura, levando-a a dialogar ou não (Simon, 2002). Em segundo lugar, pretendo qualificar a natureza do diálogo que foi empreendido pelas candidaturas, classificando-o em três categorias: 1 ) desconstrução da imagem pessoal do adversário; 2) desconstrução da imagem política do adversário; e 3) crítica ao projeto político defendido pelo adversário. Tal classificação permitirá avaliar em que medida o diálogo entre os candidatos permitiu discernir com maior ou menor clareza os contornos político-ideológicos dos projetos governamentais em disputa. Concluo que a ocorrência do diálogo entre os presidenciáveis em 2014 foi potencializada pelo aumento súbito da competitividade da campanha, desestabilizada pela ameaça de uma terceira força, que, ao final, foi incapaz de conquistar seu lugar no segundo turno. 


\section{Diálogo em campanhas eleitorais: breve revisão da literatura recente}

Escolhas democráticas pressupõem informações mútuas entre candidatos e eleitores. As campanhas eleitorais são fonte de informação sobre as candidaturas disponíveis e de discussão acerca das demandas sociais mais relevantes. A qualidade das campanhas afeta, portanto, a qualidade da democracia (Simon, 2002). Uma campanha democrática requer discussão pública ampla e livre como condição para informar suficientemente os eleitores para o voto. Nesse contexto, o diálogo aparece como critério qualificador, ou seja, seria um critério mínimo para a construção de um discurso racional em campanha. O diálogo direto ocorre apenas quando os candidatos se referem a uma mesma questão; uma vez que um candidato proponha um tema, seu adversário o discute (Xenos e Foot, 2005).

O ponto de partida teórico para este artigo, assim como para a maioria dos estudos sobre diálogo em campanhas eleitorais, é o pressuposto downsiano de que a maximização de votos visando à vitória eleitoral é o principal objetivo a determinar as estratégias de campanha dos candidatos (Downs, 1957)2. A principal implicação prática desse pressuposto é a de que as candidaturas evitarão assumir posições polêmicas que polarizem a disputa e afastem de si potenciais eleitores, preferindo posições ambíguas a posições rígidas. A ambiguidade, nesse sentido, é mais propensa a construir uma pluralidade de votos que assegure o sucesso eleitoral. Uma consequência importante desse posicionamento ambíguo seria o comprometimento da clareza das propostas apresentadas, dificultando a identificação das alternativas existentes e, finalmente, a escolha do eleitor.

Se, por um lado, a literatura acadêmica recente em torno do tema apresenta um diagnóstico geral de baixo índice de diálogo nas dinâmicas eleitorais contemporâneas, por outro, alguns autores verificam que, quanto menos os eleitores apoiam suas decisões eleitorais em vínculos partidários, maior é a importância do voto baseado em questões da pauta pública, o que pressiona os candidatos a discutirem as mesmas questões, ampliando a convergência temática ${ }^{3}$ e o diálogo nas campanhas (Kaplan, Park e Ridout, 2006). Desse modo, a fragilidade dos vínculos partidários da maioria do eleitorado brasileiro, diagnóstico generalizado na literatura acadêmica especializada no tema, consistiria em um incentivo para a ocorrência de diálogo nas campanhas eleitorais brasileiras.

O diálogo, para além de sua definição semântica, é um conceito que se presta à produção de conhecimento em várias áreas das ciências humanas, desde a própria linguística, passando pela filosofia, chegando à ciência política. Em sua definição estrita, o diálogo corresponde à interlocução entre duas ou mais pessoas, através da utilização do discurso oral ou escrito, a fim de que se tornem públicos seus pontos de vista acerca de uma mesma questão. Assumindo como premissa que as escolhas eleitorais são fruto da

\footnotetext{
2 Ver a respeito: Stokes (1963), Page (1978), Simon (2002), Xenos e Foot (2005).

${ }^{3}$ A convergência temática ocorre quando é possível identificar temas comuns sobre os quais as candidaturas assumem publicamente uma posição.
} 
racionalidade de seus agentes e que os cidadãos comuns estão diante de candidaturas alternativas, é possível supor que o ambiente informacional das campanhas interfira diretamente na qualidade dos processos de escolha. Conhecer os diferentes pontos de vista das candidaturas alternativas sobre questões da pauta pública favorece a tomada de decisão pelo eleitor, potencializando a qualidade do ambiente informacional de uma campanha. Logo, é possível afirmar que a ocorrência do diálogo é um indicador razoável para aferir o potencial democrático em processos eleitorais.

Entretanto, utilizando o mesmo critério de racionalidade, assumindo, porém, o ponto de vista das elites políticas, dialogar em campanhas pode ser considerado uma estratégia irracional. Segundo Simon (2002), dialogar em campanha seria irracional já que, de acordo com os dados por ele analisados ${ }^{4}$, quem dialoga tende a perder a eleição. Nesse aspecto, o autor considera estritamente a referência direta ao adversário ou à sua posição com relação a alguma questão da pauta pública. Esse tipo de diálogo, segundo ele, tenderia à rarefação, visto que não é funcional ao propósito último do processo eleitoral, ou seja, a aquisição de votos. Segundo esse argumento, o diálogo indireto seria a estratégia mais eficaz e predominante nas campanhas atuais. O autor considera o diálogo indireto uma espécie de "diálogo de surdos", já que, embora os candidatos se refiram a uma mesma temática ou questão, não explicitam suas posições e ignoram as do adversário.

Xenos e Foot (2005) investigaram a tomada de posição e o diálogo nos websites das campanhas durante as eleições presidenciais americanas de 2002. Os autores defendem a "tese da normalização", ou seja, que os padrões de tomada de posição e diálogo em campanhas online são similares àqueles encontrados em campanhas off-line, o que permitiria a utilização do mesmo enfoque analítico independentemente do formato de campanha a ser observado. Segundo eles, o diálogo na campanha se processa, fundamentalmente, de duas maneiras: direta ou indiretamente. O diálogo é considerado direto quando candidatos mencionam diretamente o oponente, a fim de marcar suas diferenças de posição a respeito de determinado tema. O diálogo indireto ocorre quando candidatos assumem posições ou fazem afirmações sobre um mesmo tema, sem mencionar o oponente diretamente, mas permitindo ao eleitor comparar propostas e tomar decisões informadas (Xenos e Foot, 2005, p. 171). Neste artigo tratamos apenas do diálogo direto.

A maior parte da literatura acadêmica a respeito do potencial dialógico das campanhas atuais identifica como principal padrão comportamental das candidaturas a escassez de diálogo, tanto direto quanto indireto. A estratégia preferencial seria investir em temas que favoreçam a candidatura, evitando aqueles que, porventura, venham a afastar eleitores. Quando provocado pelo adversário a manifestar-se a respeito de um determinado tema sobre o qual não tem domínio ou apresenta desempenho pregresso

\footnotetext{
${ }^{4}$ Adam Simon analisa dados colhidos durante a campanha para governador da Califórnia em 1994.
} 
negativo, o candidato optaria por ignorar a temática, evitar o conflito e fortalecer um tipo de agenda publicamente reconhecida como sua especialidade. Novamente, o discurso racional, condição para uma democracia qualificada, seria prejudicado, assim como a decisão do eleitor.

A tese da propriedade temática tem apresentado alto poder explicativo na análise da escassez de diálogo em campanhas, sendo incorporada a diversos estudos recentes sobre o tema (Budge e Farlie, 1983; Petrocik, 1996; Petrocik, Benoit e Hansen, 2003; Simon, 2002; Kaplan, Park e Ridout, 2006). Segundo essa teoria, alguns partidos teriam ampla credibilidade junto ao eleitorado para discutir e propor soluções políticas para determinadas questões. Dessa forma, assim como partidos verdes teriam a propriedade temática sobre questões ecológicas, partidos social-democratas possuiriam maior habilidade para tratar de assuntos relacionados às políticas de bem-estar social. A saliência de uma questão, determinada pelas preferências do eleitorado, combinada à propriedade dessa questão atribuída a um dos partidos em disputa, seria chave na definição do voto. Desse modo, segundo essa abordagem, uma temática seria tratada na campanha de um partido apenas quando o eleitorado percebesse que seu candidato seria o mais capacitado em lidar com ela, evitando, simultaneamente, promover a candidatura do adversário ao reduzir a saliência de uma temática que fosse favorável a este último. De acordo com essa teoria, a convergência temática pode nunca ocorrer, mesmo em campanhas competitivas, quando, em tese, sua probabilidade aumenta ${ }^{5}$, já que as candidaturas abordam apenas temáticas que Ihes favoreçam junto ao eleitorado e evitam aquelas que sejam percebidas publicamente como próprias do adversário.

Entretanto, a ocorrência de uma campanha não dialógica não seria razoável na medida em que algum grau de diálogo sempre estará presente nas estratégias de campanha que visam à desconstrução da imagem do adversário. Mesmo que as provocações mútuas nunca sejam respondidas, fica cumprida para o eleitorado a função dialógica de exposição do contraditório entre as candidaturas, que assegura a escolha democrática. A escolha pela não resposta comporta o risco de que o eleitor aceite a versão crítica do adversário ou então que decida por ignorar a temática também. Ou seja, o diálogo limitado obstrui, mas não anula a escolha democrática.

Ademais, a estabilidade da propriedade temática tem sido questionada na literatura mais recente. Walgrave, Lefevere e Nuytemans (2009) investigaram se a propriedade temática é um ativo partidário permanente ou transitório. Ou seja, os autores questionaram se, uma vez conquistada a propriedade de um tema por um determinado partido, ele pode vir a perdê-la; questionaram ainda como é possível conquistar a propriedade de uma questão que não tenha sido apropriada previamente. Com base em um amplo survey eleitoral realizado na Bélgica, os autores testaram se a propriedade temática é uma condição estável ou um processo dinâmico e concluíram pela segunda

\footnotetext{
${ }^{5}$ Essa questão é abordada mais adiante neste artigo.
} 
opção, demonstrando que a exposição midiática pode levar a mudanças significativas na propriedade de determinados temas da pauta pública. Segundo os autores, por um lado, os temas não previamente associados a algum partido poderiam ser apropriados em função da performance comunicativa do líder partidário; por outro lado, o efeito de questões previamente apropriadas dependeria do equilíbrio de sua visibilidade na mídia.

Adam Simon (2002) já afirmava que a pauta temática proposta pelos meios de comunicação durante as campanhas eleitorais serviria de incentivo ao diálogo entre as candidaturas. Segundo o autor, as diretrizes editoriais da mídia irão importar na medida em que as estratégias de campanha são delineadas a fim de atrair o maior número possível de eleitores, fazendo com que as candidaturas procurem discutir temas que produzem maior impacto no eleitorado. Os meios de comunicação, embora suscetíveis à pauta sugerida pelas candidaturas, contribuem para a agenda do processo eleitoral, já que constituem a principal fonte de informação política (McCombs e Shaw, 1972). Uma vez que um tema se constitua em pauta pública, não deverá ser ignorado pelos candidatos, propiciando, ao menos, um diálogo indireto entre eles.

Há ainda uma outra condição impeditiva da abolição do diálogo em campanhas eleitorais: candidatos desafiantes não podem ignorar a agenda governamental na medida em que se torne pauta da campanha. O mesmo acontece com os meios de comunicação, que veem sua capacidade de pautar as campanhas limitada por parte da agenda governamental considerada relevante pela maioria do eleitorado. Se determinadas políticas públicas ganham popularidade e tornam-se decisivas na escolha eleitoral, não podem ser ignoradas, mesmo sendo propriedade temática provisória da candidatura governamental: assim foi com as políticas econômicas durante os governos do PSDB e seu impacto no controle inflacionário e na estabilidade da moeda, como também as políticas sociais dos governos do PT e seu impacto na redução da pobreza e na ampliação das classes médias. Nesses casos, o diálogo, mesmo que indireto, é inevitável para as candidaturas desafiantes. Essa é a razão pela qual candidatos de oposição tendem a dialogar mais, se comparados a candidatos que buscam a reeleição.

Budge e Farlie (1983) apontaram o fato de que algumas questões da pauta pública não pertencem definitivamente a nenhum partido, mas podem ser anexadas temporariamente em função da performance, como é o caso das questões relativas à economia nacional e às relações internacionais. Tais questões irão variar conforme a situação corrente, quem são os líderes partidários e quais têm sido as ações governamentais. A variação dos resultados nesses campos ao longo do tempo estimula o confronto de ideias e assegura a ocorrência de diálogo durante as campanhas.

A própria teoria downsiana do eleitor mediano contribui para a conclusão de que algum grau de diálogo sempre estará presente em eleições competitivas. Segundo essa teoria, que convergirá para a tese da tendência centrípeta dos partidos políticos nas democracias contemporâneas, quanto mais competitiva a corrida eleitoral, maior será a pressão para que os candidatos pareçam mais moderados ideologicamente. Nesse sentido, 
a fim de criar uma imagem mais moderada, um candidato pode vir a assumir posições convergentes com a de seu adversário, especialmente em questões pertencentes a esse último (Kaplan, Park e Ridout, 2006).

Nesse sentido, a convergência temática pode significar, ao contrário do diálogo esperado, uma maior ambiguidade, em lugar de um significativo contraste nos posicionamentos das candidaturas, e pode não contribuir para o esclarecimento do eleitor quanto às opções políticas disponíveis. Ou seja, os candidatos podem simplesmente ecoar o posicionamento uns dos outros sem oferecer uma clara alternativa aos eleitores (Sigelman e Buell Jr., 2004). Sigelman e Buell Jr. trabalharam uma massiva base de dados acerca das campanhas presidenciais nos Estados Unidos na cobertura da imprensa a partir dos anos 1960 e encontraram um surpreendente percentual médio de $75 \%$ de convergência temática entre adversários republicanos e democratas no período analisado. Embora não tenham se proposto a uma análise do contraste de posicionamentos, os autores contrariaram boa parte de literatura acadêmica que sustentava que os candidatos tendiam a abordar exclusivamente questões que Ihes eram favoráveis e a ignorar aquelas que favoreciam a candidatura adversária.

Tanto o posicionamento quanto o diálogo variam conforme a intensidade das campanhas. Kaplan, Park e Ridout (2006) criaram um índice de convergência temática em campanhas eleitorais, condição mínima para ocorrência de diálogo entre as candidaturas, e confirmaram que há um aumento nesse índice à medida que aumenta a competitividade. Campanhas disputadas, em que os candidatos são conhecidos e o resultado é incerto, incentivam candidatos a assumirem posições em um maior número de temas do que campanhas apáticas, quando a vitória do candidato mais forte é dada como certa. Sendo maior o número de temas discutidos, haverá provavelmente maior ocorrência de diálogo indireto.

Finalmente, a literatura acadêmica recente aponta para as diferenças de posicionamento entre candidatos à reeleição e desafiantes. Um dos aspectos mencionados seria a hipótese de que candidatos à reeleição tendem a discutir menos questões políticas do que candidatos desafiantes. Como os candidatos à reeleição possuem um histórico mais robusto de performance no cargo e uma significante vantagem em termos de visibilidade, acabam focando mais em questões relativas a caráter, competência, experiência e integridade, quando comparados aos adversários (desafiantes).

Esses dois últimos tópicos serão especialmente considerados na medida em que constituem uma dimensão relevante para o fenômeno empírico que se pretende abordar na pesquisa: a ocorrência e a natureza do diálogo entre as candidaturas presidenciais brasileiras do Partido dos Trabalhadores (PT) e do Partido da Social Democracia Brasileira (PSDB) em 2014. O aumento da competitividade da campanha realmente torna significativa a ocorrência do diálogo entre as candidaturas? Será que, de fato, candidatos à reeleição dedicam-se menos do que os desafiantes à discussão política? Finalmente, 
candidatos desafiantes discutem mais temas políticos e insistem mais no diálogo com seus adversários do que os que buscam a reeleição?

A fim de avaliar essas questões, elaborei três parâmetros classificatórios do diálogo entre as candidaturas: 1) desconstrução da imagem pessoal do adversário; 2) desconstrução da imagem política do adversário; e 3) crítica ao projeto político defendido pelo adversário. Cada uma dessas categorias resulta em consequências distintas para a democracia. A primeira seria a mais inadequada, uma vez que não contribui em nada para a escolha do eleitor. Ataques pessoais não consideram a dimensão política da disputa, desqualificam o debate e empobrecem a democracia. Candidatos que fazem ataques pessoais, em geral, perdem a eleição. Esse, portanto, é um recurso irracional, já que é ineficaz quanto ao seu propósito: ganhar a confiança do eleitorado e seu voto. A segunda categoria visa demonstrar a incompetência do adversário nas diversas áreas de atuação do Estado. Esse é um recurso que só é válido para usar com adversários que já tenham alguma experiência administrativa. Por essa razão, deverão ser usados com maior frequência pelos candidatos ou partidos desafiantes. Como o objetivo é demonstrar a incompetência do adversário, este pode tornar-se um recurso perigoso, desde que a estratégia utilizada seja a da desqualificação e do desdém, o que indicaria soberba de quem o usa, um valor aristocrático que é incompatível com a democracia. A terceira seria a categoria mais favorável à qualificação de uma campanha democrática, pois dá a oportunidade ao eleitor de comparar propostas. Seria um recurso com maior potencial de indução de resposta do adversário, com o intuito de defender sua plataforma governamental e, por essa razão, permitiria ao eleitorado tomar uma decisão mais informada e mais qualificada.

\section{Apontamentos teórico-metodológicos}

O primeiro passo a ser dado na análise dos dados é explicar a metodologia que foi utilizada, ou seja, como se processou a coleta e a organização de dados e informações.

Foram assistidos e analisados todos os programas eleitorais diários da campanha na televisão de primeiro e segundo turnos: 187 programas em bloco e 66 spots veiculados entre os dias 19 de agosto e 2 de outubro de 2014; 34 programas e 84 spots veiculados entre os dias 9 e 24 de outubro de 2014. Programas e spots repetidos foram descartados. Em cada um dos programas em bloco foram feitas marcações separando o número de peças publicitárias veiculadas. Os spots contaram como uma única peça. Dessa forma, foi possível mensurar a ocorrência das distintas categorias acima explicadas, contabilizando cada uma delas apenas uma vez em cada peça. Essa técnica permite que se contabilize a utilização de um, dois ou dos três recursos dialógicos, mas apenas uma vez cada um, pois a presença de cada um no discurso já é suficiente para caracterizar seu uso. Dividir os programas em bloco em peças publicitárias tem a vantagem de driblar a diferença de tempo de veiculação de cada candidatura. As estatísticas de ocorrência de diálogo são 
calculadas a partir do número de peças em que aparecem e não a partir do tempo em que são utilizadas, o que poderia resultar em uma distorção nos resultados, que levaria a crer que o candidato com maior tempo teria maior predisposição ao diálogo.

Feitas as marcações, foi totalizado o número de peças veiculadas no período para cada uma das candidaturas. Esse número é a base de cálculo para verificar a incidência dos recursos dialógicos, individualmente ou de forma agregada. O uso de cada um dos recursos foi contabilizado para cada uma das candidaturas. Primeiramente, somei os recursos em sua totalidade e calculei seu percentual de incidência ao longo de toda a campanha, dividido por turnos, a fim de verificar a disposição para o diálogo de cada uma das candidaturas. Em seguida, calculei a incidência de cada uma das estratégias em cada candidatura a fim de verificar se houve diferença de uso entre elas e qual foi essa diferença: Qual foi a estratégia dominante? Qual foi a segunda estratégia utilizada e em qual proporção? Qual foi a estratégia menos importante para cada uma das candidaturas?

Antes de partir para os resultados propriamente ditos, gostaria de explorar algumas das categorias teóricas revisadas na literatura recente sobre diálogo em campanhas.

Em primeiro lugar, não trabalhei a categoria diálogo indireto, que poderia tornar a análise muito subjetiva. Selecionei apenas os exemplos de diálogo direto, ou seja, quando o adversário e/ou seu partido são explicitamente mencionados. Se incluísse os exemplos de diálogo indireto, a incidência de diálogo teria sido ainda mais expressiva do que já foi, demonstrando que a tese de ausência de diálogo nas campanhas eleitorais contemporâneas não se confirma, ao menos no caso da eleição presidencial brasileira de 2014.

Em segundo lugar, verificou-se a convergência temática em ao menos cinco ocasiões durante o segundo turno: no dia do professor (15/10), no dia seguinte a cada um dos debates televisivos (Bandeirantes: 15/10, SBT: 17/10, Record: 20/10) e no último dia da propaganda eleitoral (24/10), sobre o lançamento da revista Veja no dia anterior. Essa convergência temática ocorreu simultaneamente, ou seja, no mesmo dia. Outras convergências foram identificadas, mas uma análise com precisão demandaria um trabalho de coleta de dados temáticos específicos nesse sentido ${ }^{6}$. De qualquer forma, nessas cinco ocasiões os eleitores puderam conhecer os distintos pontos de vista de cada uma das candidaturas a respeito do tema. Nos debates, cada um valorizou seus melhores momentos, mas sempre em ataque ao outro. Sobre a matéria de capa da Veja, cada um deu sua opinião sobre o semanário e sobre o conteúdo das denúncias apresentadas. A convergência temática mais interessante foi a do dia dos professores, que possibilitou aos candidatos apresentarem suas propostas para a educação e a sua visão sobre o papel social dos professores.

\footnotetext{
6 O estudo da convergência temática permite sofisticar a análise do diálogo em campanha, possibilitando ampliar a compreensão sobre ele, e deve ser desenvolvido em uma etapa posterior da pesquisa.
} 
Em terceiro lugar, foram verificadas algumas ocorrências interessantes, especialmente na campanha do PSDB. Não havia como ignorar o sucesso das políticas sociais dos governos do PT, então a campanha buscou reafirmar seu compromisso na manutenção de programas como o Bolsa Família, o Minha Casa Minha Vida, entre outros, sempre adicionando a informação de que tais programas eram falhos e precisavam ser aprimorados. Especialmente com relação ao Bolsa Família, houve uma tentativa do PSDB de se apropriar da "paternidade" do programa, argumentando que ele já existia, de forma embrionária, durante os governos FHC; segundo a campanha, o Bolsa Família seria uma fusão de vários programas sociais existentes naquela época. Essa é uma estratégia original para lidar com a propriedade temática: deslocá-la do adversário para si. Não encontrei nenhum caso similar na literatura. Entretanto, importa ressaltar que políticas sociais nunca se constituíram em propriedade temática do PSDB. Suas políticas sociais eram minoritárias no conjunto de ações do governo. Seu campo de domínio sempre foi a macroeconomia. O Bolsa Família é um dos maiores programas governamentais do PT e uma de suas principais marcas. Seu impacto na redução da pobreza no Brasil é reconhecido internacionalmente. Dizer, como afirmou o candidato do PSDB, que seu partido está no "DNA" do Bolsa Família, em uma estratégia de reverter para si a propriedade temática que o PT tem sobre ele, não me parece que tenha sido eficaz. O impacto que ele teve sobre a vida das famílias carentes ocorreu na vigência dos governos do PT, assim como o controle da inflação e a estabilidade da moeda ocorreram nos governos do PSDB; o eleitor tem capacidade de distinguir isso.

Dito isso, partimos para a análise proposta, dividida entre o primeiro e o segundo turno das eleições.

\section{O primeiro turno da eleição presidencial de 2014: como dialogaram PT, PSDB e PSB?}

\section{O HGPE em bloco (primeiro turno)}

Em primeiro lugar, importa ressaltar que os programas em bloco mais fragmentados em peças eram os do PT: em média, 10 peças por programa; contabilizaramse 610 peças no primeiro turno da campanha. Os programas do PSDB eram bem menos fragmentados do que os do PT: 4,4 peças em média por programa, somando-se 324 peças no primeiro turno. As peças do PSDB eram mais longas do que as do PT, o que atribuía à propaganda eleitoral desse último uma maior dinamicidade. Já os programas do PSB eram os menos fragmentados, apresentando uma média de 2,4 peças por programa, 125 peças no total, e isso é explicado pelo tempo significativamente mais curto de campanha do PSB com relação ao de seus adversários. 


\section{Gráfico 1}

Incidência de diálogo direto nas campanhas do HGPE em bloco (primeiro turno) - Percentual do uso do tempo (\%)

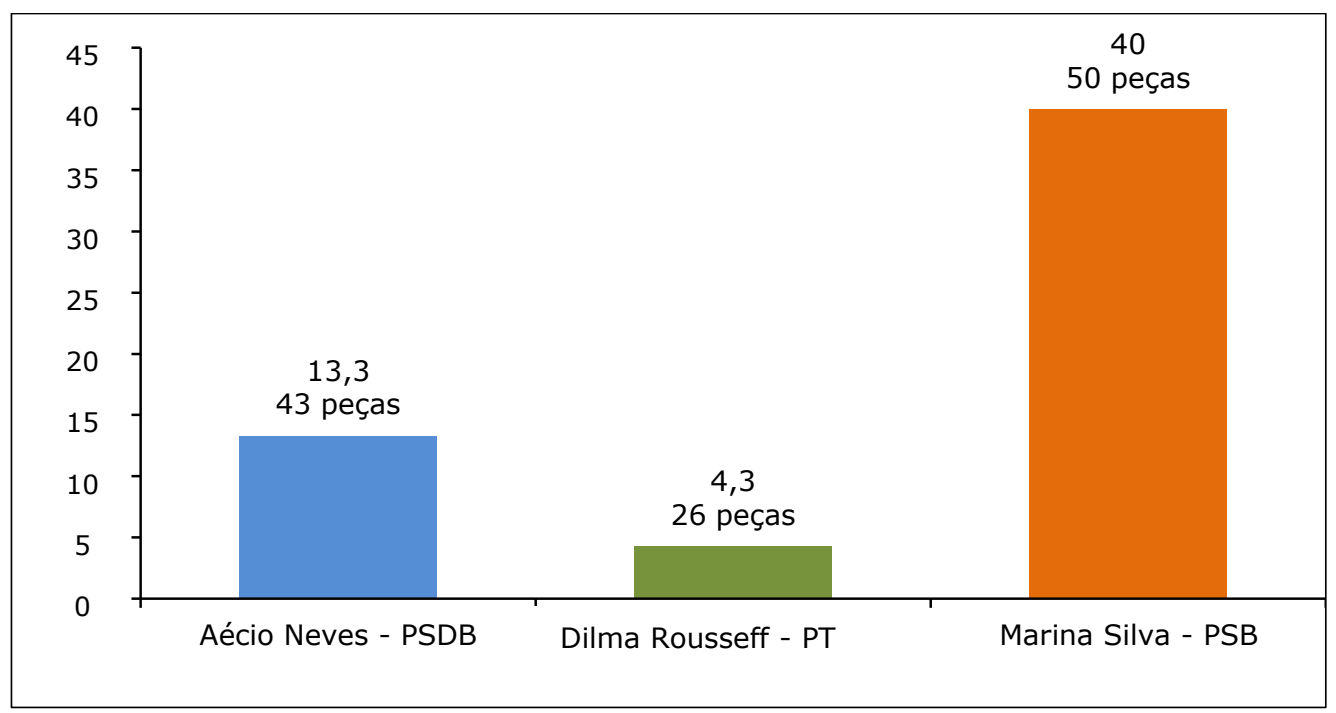

Fonte: Dados coletados na propaganda eleitoral televisiva de 2014 no acervo do Doxa-Iesp. Classificação própria.

No cômputo geral, as menções diretas aos adversários, ou seja, a ocorrência de diálogo direto, foram maiores na campanha do PSB, apesar do tempo exíguo de televisão. Foram 50 ocorrências de diálogo direto, o que significa que a candidata Marina Silva buscou o diálogo com seus adversários em $40 \%$ da sua propaganda em bloco. O PSDB dialogou diretamente com seus adversários em 43 peças de campanha, perfazendo um total de $13,3 \%$ de uso dessa estratégia eleitoral comunicativa na televisão. Importa ressaltar que o diálogo empreendido em ambas as campanhas mencionadas visava prioritariamente a candidatura do PT, ocupante do cargo de presidente em busca de reeleição. O PT, por sua vez, foi o partido que menos utilizou a estratégia do diálogo direto com seus adversários na propaganda em bloco, registrando-se apenas 26 ocorrências nesse sentido, um total de $4,3 \%$.

Até aqui, nenhuma novidade. Partidos de oposição tendem a dialogar mais, uma vez que não têm o patrimônio governamental a seu favor, e se apoiam nas fragilidades da atual gestão para criticá-la e mostrar que serão capazes de superar esses problemas, preferencialmente apresentando propostas alternativas. 
Gráfico 2

O uso dos tipos de diálogo pelas candidaturas no HGPE em bloco no primeiro turno (\%)

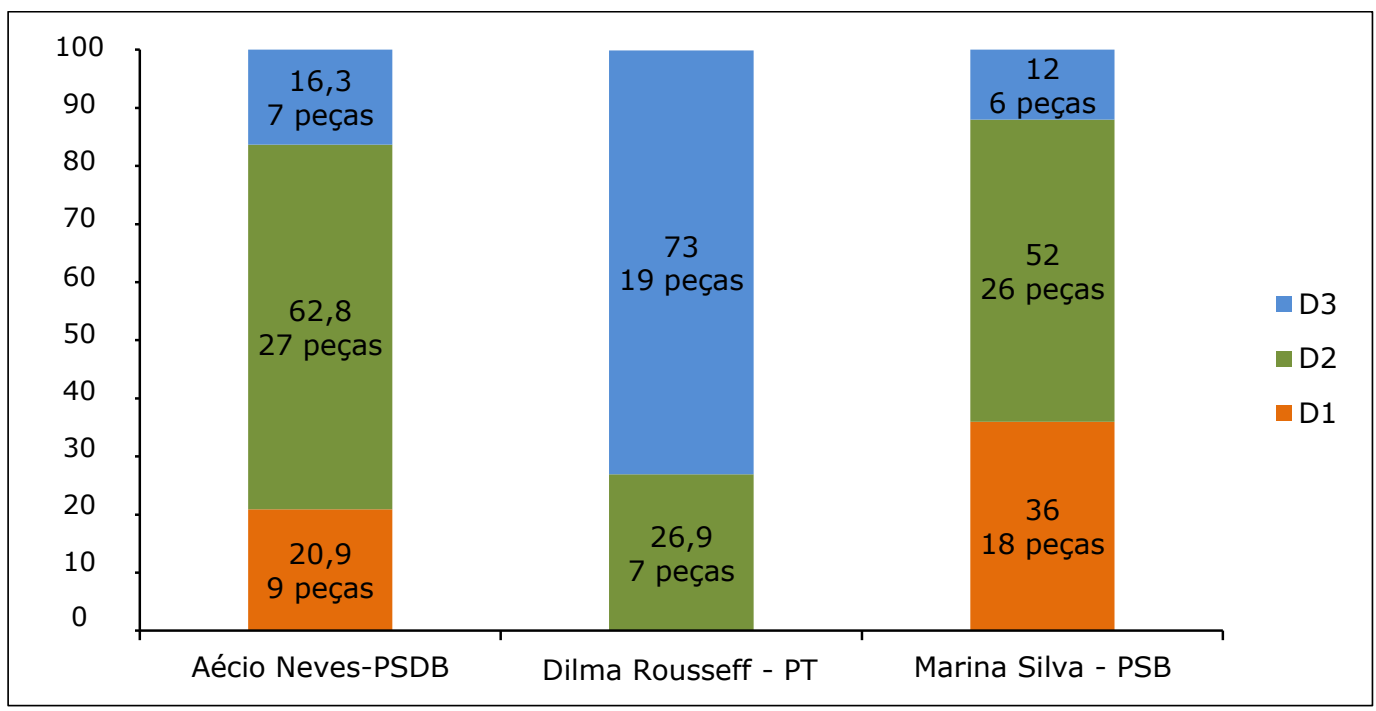

Fonte: Dados coletados na propaganda eleitoral televisiva de 2014 no acervo do Doxa-Iesp. Classificação própria.

Legenda: $\mathrm{D} 1$ = desconstrução da imagem pessoal do adversário; D2 = desconstrução da imagem política do adversário; D3 = crítica ao projeto político defendido pelo adversário.

Desdobrando-se a incidência das categorias sobre cada uma das campanhas, descobrimos que a segunda categoria foi a mais utilizada como estratégia de diálogo entre as candidaturas de oposição. Ou seja, na maioria das vezes que os candidatos se referiam ao seu adversário, o faziam no intuito de desconstruir sua imagem política, buscando apontar as falhas administrativas de cada um. Para candidaturas desafiantes, essa é uma estratégia mais comum, pois possuem um amplo material a ser explorado, já que seu adversário é, ao mesmo tempo, o responsável pelo governo. Em 62,8\% das tentativas de diálogo, o PSDB buscou desconstruir a imagem política de seu adversário. O PSB utilizou a mesma estratégia em $52 \%$ de seu diálogo direto. O PT buscou criticar a capacidade administrativa e/ou ações governamentais de seus adversários em $26,9 \%$ de suas peças que continham diálogo direto. Em relação a Aécio Neves, a campanha de Dilma focou nos erros de sua gestão durante oito anos no governo de Minas Gerais. Em relação a Marina Silva, a campanha do PT focou em seu trabalho no Ministério do Meio Ambiente durante o governo Lula e na incoerência de seu discurso de presidenciável. Seguem alguns exemplos do uso em cada candidatura da segunda estratégia dialógica:

Hoje eu quero mostrar pra vocês como os erros do governo Dilma, que vêm se acumulando, causam enormes prejuízos aos brasileiros e paralisam o Brasil. (...) E nós chegamos a esse ponto porque esse governo que aí está faz sempre as escolhas erradas, não planeja, é o governo do improviso. É um 
governo que não cuida do dinheiro do seu imposto. Isso porque o PT se julga dono do Brasil e acha que pode fazer tudo o que quer (Aécio Neves, HGPE 23/9/2014).

Não adianta maquiar. Dilma prometeu defender a Petrobras e o Brasil inteiro sabe o que aconteceu. Dilma disse que ia dar prioridade à educação, mas o Brasil não cumpriu a meta contra o analfabetismo. Dilma disse que ia controlar a economia. A inflação voltou e o país está em recessão. Podem maquiar o quanto quiserem. Por mais propaganda que Dilma e o PT façam, não conseguem esconder a realidade (locutor em off, campanha do PSB em 20/9/2014).

As contradições de Aécio. O povo se lembra que o governo do PSDB quebrou o Brasil por três vezes, que praticou as maiores taxas de juros de toda a história. Em março de 1997, o senhor (dirigindo-se a Aécio Neves durante debate) declarou que pode ser inclusive que chegue o momento de discutirmos a privatização da Petrobras, mas não será agora. Recentemente o senhor voltou ao tema dizendo que a Petrobras não está no radar da privatização do PSDB. Quais as privatizações que estão no radar? (Dilma Rousseff, reprodução de debate na televisão, HGPE 30/9/2014).

Entretanto, a estratégia mais utilizada pelo PT durante o HGPE em bloco do primeiro turno das eleições de 2014 foi a terceira: "crítica ao projeto político defendido pelo adversário". Em 73,1\% de seus diálogos, a campanha de Dilma Rousseff buscou explorar o projeto político sustentado pelo adversário em comparação ao seu próprio. Novamente, não surpreende o resultado, uma vez que cabe ao candidato à reeleição fazer com que o eleitor acredite que sua vida irá piorar com a alternância na condução governamental. Os candidatos do PSDB e do PSB investiram bem menos nessa estratégia: $16,3 \%$ e $12 \%$, respectivamente. Essa foi a terceira estratégia na qual ambos investiram. Importa lembrar que esse é um tipo de diálogo que permite ao eleitor uma maior comparação entre os projetos políticos em disputa, qualificando o ambiente informacional. Abaixo, seguem alguns exemplos desse tipo de diálogo que aqui está sendo tratado como qualificador da democracia, na medida em que apresenta distintas escolhas ao eleitorado no caso de voto em um ou outro candidato.

Aécio é a favor de diminuir a maioridade penal em caso de reincidência e crimes hediondos. A Dilma é contra. A Marina também é contra. E você, é contra ou a favor? (apresentadores da propaganda eleitoral do PSDB, HGPE $13 / 9 / 2014)$.

Está na hora de superar a velha disputa do poder pelo poder e unir a sociedade brasileira em torno de um projeto que não é só de um partido. Para isso 
fizemos um plano de governo reunindo milhares de pessoas. Para mudar o Brasil é preciso ouvir o Brasil (Marina Silva, PSB em 26/8/2014).

Marina tem dito que, se eleita, vai fazer a autonomia do Banco Central. Parece algo distante da vida da gente, né? Parece, mas não é. Isso significaria entregar aos banqueiros um grande poder de decisão sobre a sua vida e a de sua família. Os juros que você paga, seu emprego, preços e até salários. Ou seja, os bancos assumem um poder que é do presidente e do Congresso, eleitos pelo povo. Você quer dar a eles esse poder? (locutor em off, campanha do PT em 9/9/2014).

Ambas as candidaturas adversárias desafiantes investiram, em segundo lugar, na primeira estratégia de diálogo direto: o ataque pessoal ao adversário. A candidatura do PSB foi bem mais enfática nessa estratégia do que a do PSDB: enquanto $36 \%$ de suas estratégias de diálogo apontavam nessa direção, 20,9\% da campanha de Aécio dedicouse a atacar pessoalmente seus adversários. Esse resultado inverte um senso comum amplamente disseminado de que a candidatura do PT teria sido responsável pela derrota de Marina Silva no primeiro turno através de uma virulenta campanha de ataques pessoais. O que se notou na propaganda eleitoral do PSB é que, enquanto a candidata se dizia vilipendiada pela adversária, fazia contra esta aquilo de que que ela mesma dizia estar sendo vítima. Entretanto, não foi registrada nenhuma estratégia de diálogo do primeiro tipo no HGPE em bloco do primeiro turno da campanha do PT. Alguns exemplos da campanha do PSB e do PSDB nesse sentido seguem abaixo:

A Dilma nunca tinha governado antes e deu no que deu. O Brasil parou de crescer e a inflação está de volta. A Marina também nunca governou e muda de posições ao sabor das circunstâncias. Eu apresento a você um projeto debatido em todo Brasil, com as melhores cabeças, para transformá-lo em realidade (Aécio Neves, campanha do PSDB em 4/9/2014).

Quem não foi nem vereadora e vira presidente do Brasil não entende isso, come pela boca do marqueteiro, come pela boca do assessor. Não me venha chamar de mentirosa. Mentira é quem diz que não sabe que tinha roubo na Petrobras. Mentira é quem diz que não sabe o que está acontecendo na corrupção desse país (Marina Silva, durante encontro com apoiadores de campanha, HGPE 2/10/2014).

Os documentos do Senado registram a verdade: Marina fez duas vezes o contrário do que diz. Mudar de opinião ainda vá lá. Agora, falar que fez o que 
não fez, isso tem outro nome (locutor em off, veiculado em spot do PT em $28 / 9 / 2014)^{7}$.

O que é possível supor, nesse caso, é que a candidata do PSB estivesse se referindo à circulação de informações pela internet, veículo com o qual não estou trabalhando neste artigo. Optei por comparar discursos em um mesmo veículo, pois, como já demonstrado em diversos estudos, as estratégias comunicativas de campanha variam muito entre os diferentes veículos, sejam eles o rádio, a televisão ou a internet.

\section{HGPE em spots de campanha no primeiro turno}

Os spots de campanha são inserções de até 30 segundos na programação normal das redes de TV aberta, assim como no rádio, que aqui não está sendo investigado. O objetivo é transmitir mensagens curtas, de modo ágil, visando atingir positiva ou negativamente o eleitorado com relação a determinada candidatura. Por serem curtos, contabiliza-se apenas uma peça por spot, descartando-se imagem de abertura e encerramento, em que não caberia a possibilidade de diálogo. Por ser uma linguagem mais objetiva do que o bloco, é possível supor que os spots sirvam de mecanismo propício para atingir candidaturas adversárias. Foram analisados 66 spots da campanha presidencial do primeiro turno de 2014: 18 do PSDB, 38 do PT e 10 do PSB.

\section{Gráfico 3}

\section{Incidência de diálogo direto nos spots das campanhas no primeiro turno Uso do tempo (\%)}

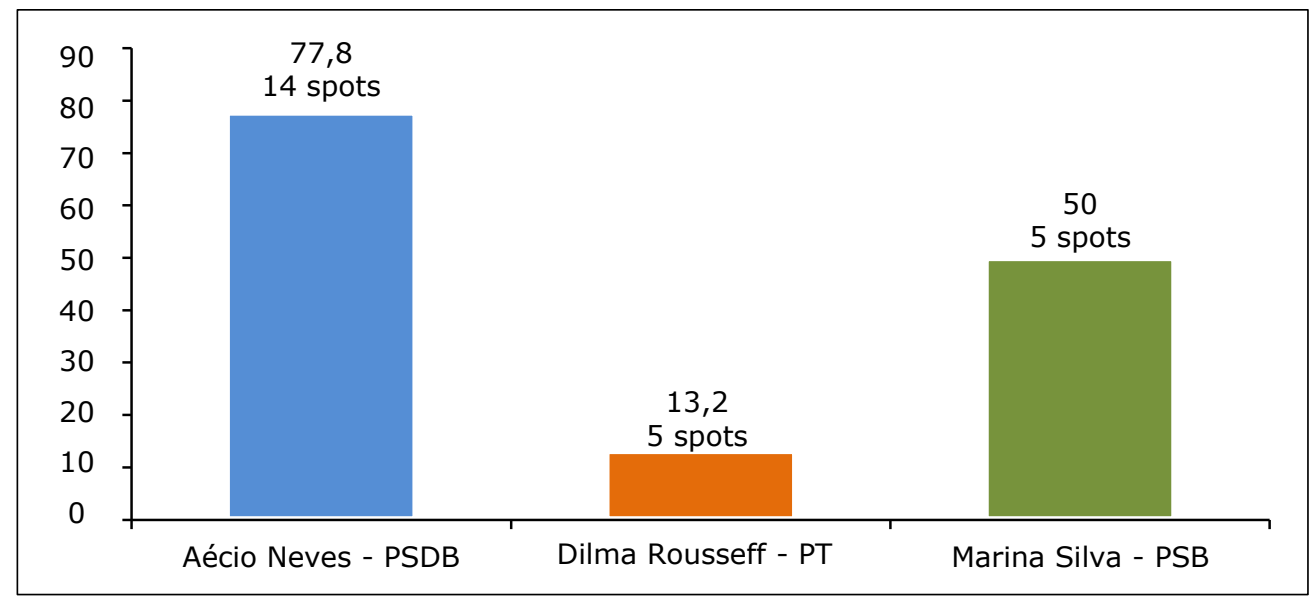

Fonte: Dados coletados na propaganda eleitoral televisiva de 2014 no acervo do Doxa-Iesp. Classificação própria.

7 Transcrevi a passagem de um spot como exemplo do primeiro tipo de diálogo do PT, pois não houve registro desse D1 na sua propaganda em bloco do HGPE durante o primeiro turno. 
O primeiro dado que chama a atenção no uso de estratégias comunicativas nos programas em bloco e nos spots, no que se refere à busca pelo diálogo com os adversários, é uma inversão na intensidade aplicada pelas candidaturas desafiantes. Ou seja, enquanto a candidatura de Marina Silva buscou mais o diálogo nos programas televisivos em bloco, Aécio Neves o fez na exibição de seus spots. Em 77,8\% dos spots do PSDB analisados verificou-se alguma tentativa de diálogo com as adversárias, especialmente com a candidata à reeleição. É possível mesmo afirmar que o uso dos spots na candidatura de Aécio Neves tinha como objetivo confrontar a(s) adversária(s). A candidatura do PSB também ampliou o uso do diálogo como estratégia comunicativa nos spots, mas de forma bem menos intensa do que seu adversário do PSDB, ainda assim em um percentual superior em relação a seus programas em bloco: o fez na metade dos spots analisados. A candidatura do PT também ampliou significativamente sua capacidade de diálogo nos spots televisivos: o fenômeno foi observado em 13,2\% dos casos, em comparação aos 4,3\% verificados nos blocos de programação.

Proporcionalmente, durante os spots, o PSDB sustentou cerca de $55 \%$ das estratégias dialógicas da campanha. O PSB veio em seguida, com aproximadamente $35 \%$ dos diálogos. Por último, o PT, com apenas $9 \%$ da busca por diálogos com adversários. Assim como analisado no HGPE em blocos, o comportamento das campanhas seguiu o padrão demonstrado na literatura: candidaturas desafiantes dialogam mais do que a candidatura à reeleição. Mas é no tipo de diálogo que empreendem que está a maior diferença entre elas.

Gráfico 4

\section{O uso dos tipos de diálogo pelas candidaturas nos spots no primeiro turno (\%)}

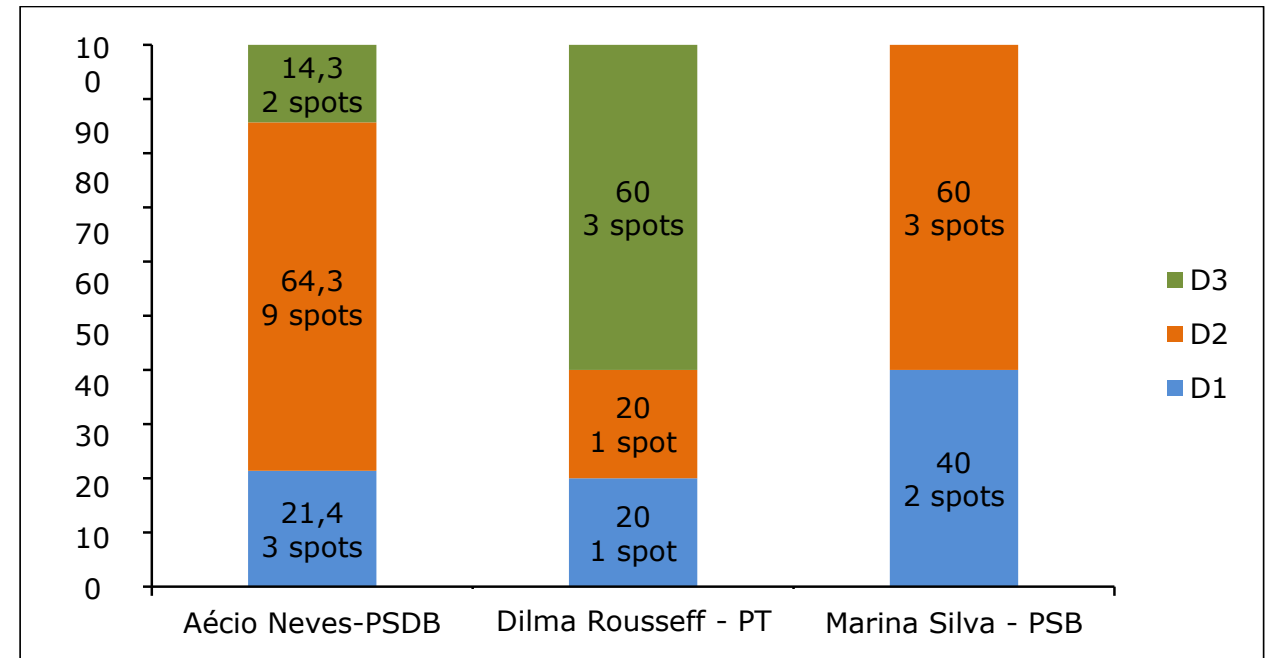

Fonte: Dados coletados na propaganda eleitoral televisiva de 2014 no acervo do Doxa-Iesp. Classificação própria.

Legenda: D1 = desconstrução da imagem pessoal do adversário; D2 = desconstrução da imagem política do adversário; D3 = crítica ao projeto político defendido pelo adversário. 
Aécio Neves investiu prioritariamente na desconstrução da imagem política do adversário (D2), assim como Marina Silva. Ambos buscavam apontar as fragilidades do governo federal sob o comando do PT. Fizeram isso em mais de $60 \%$ das vezes que tentaram dialogar. Dilma Rousseff também fez uso desse tipo de diálogo nos spots, embora em proporções significativamente menores: 20\%. Seu principal alvo era o governo de Aécio Neves no estado de Minas Gerais. Novamente, sua principal estratégia dialógica foi a terceira, crítica às propostas de campanha do adversário, em contraste com as suas. 0 que chama atenção em seus spots, entretanto, é a ampliação da estratégia de primeiro tipo, a que mais se assemelha à propaganda negativa de cunho pessoal. Nesse caso, parece que nos spots a campanha do PT se sentiu mais à vontade em mencionar negativamente o caráter de seus adversários, desafiando-os. O PT atacou, proporcionalmente, tanto quanto a campanha do PSDB (20\% e $21,4 \%$ respectivamente), sendo ambos deixados para trás pela virulência da campanha do PSB ( $40 \%$ do diálogo empreendido era dessa natureza), que sequer utilizou a terceira e mais democrática das estratégias dialógicas.

Conclusão parcial: o diálogo em campanha no primeiro turno das eleições presidenciais de 2014

Como síntese do primeiro turno, apresento o Gráfico 5, no qual é possível verificar, de forma comparada, o tipo de diálogo predominante em cada candidatura e em cada estilo de HGPE, bloco e spots: 


\section{Gráfico 5}

\section{Tipos de diálogo por candidatura em bloco e spots no primeiro turno (\%)}

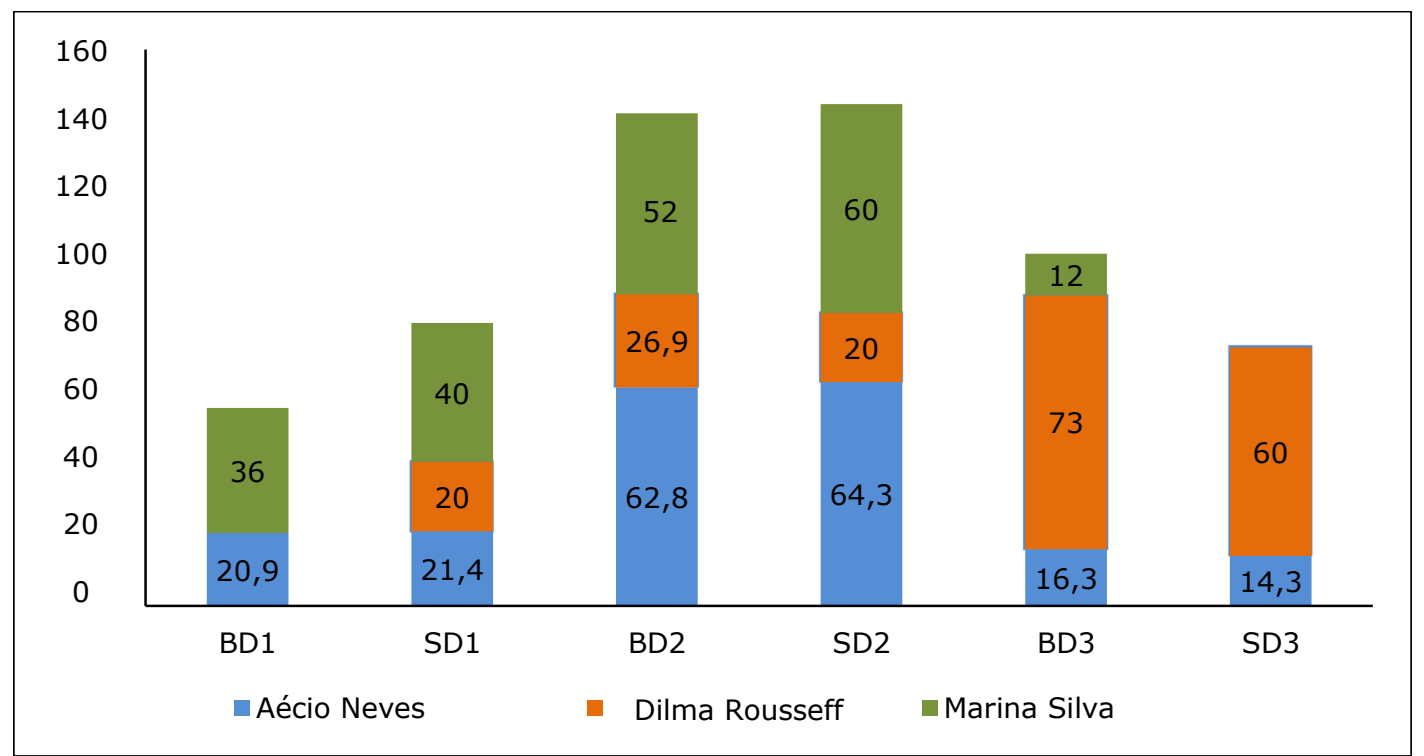

Fonte: Dados coletados na propaganda eleitoral televisiva de 2014 no acervo do Doxa-IESP. Classificação própria.

Legenda: $\mathrm{BD} 1$ = diálogo tipo 1 em bloco; $\mathrm{BD} 2$ = diálogo tipo 2 em bloco; $\mathrm{BD} 3$ = diálogo tipo 3 em bloco; SD1 = diálogo tipo 1 em spots; SD2 = diálogo tipo 2 em spots; SD3 = diálogo tipo 3 em spots.

A observação mais notória do Gráfico 5 é a coerência da campanha do PSDB na utilização de recursos de diálogo nos diferentes modelos comunicativos. Não houve diferença significativa no uso de cada tipo de diálogo entre o HGPE em bloco (BD 1, 2 ou 3 ) e spots (SD 1, 2 ou 3). Em ambos, houve predomínio da segunda estratégia (em torno de $60 \%$ ), seguida pela primeira forma de diálogo (em torno de $20 \%$ ), acompanhada de perto pela terceira (em torno de $15 \%$ ).

As outras duas candidaturas apresentaram uma variação maior no uso de cada estratégia por modelo comunicativo. No caso da campanha do PSB, houve menor discrepância no uso da primeira estratégia entre o programa em bloco e os spots, em que se verificaram percentuais semelhantes, 36\% e $40 \%$ respectivamente. Na segunda forma de diálogo, houve um aumento de $8 \%$ no uso da estratégia em spots. A terceira forma de diálogo não foi registrada em spots, tendo representado $12 \%$ dos recursos dialógicos de seu HGPE em bloco.

A candidatura mais discrepante no uso dos recursos de diálogo por forma comunicativa foi a do PT. Visivelmente o espaço comunicativo dos spots serviu a propósitos mais agressivos em termos de relacionamento com os adversários, apresentando um incremento de $20 \%$ na primeira forma de diálogo em relação ao HGPE em bloco, no qual não houve registro dessa forma. A segunda forma de diálogo, por sua vez, foi menos utilizada em spots: 7\% a menos do que seu uso em HGPE em bloco. Da mesma forma, 
houve uma redução significativa ( $13 \%$ ) no uso da terceira forma de diálogo entre os blocos e os spots.

O que esses dados demonstram é que o argumento, amplamente utilizado pela campanha tanto de Aécio Neves quanto de Marina Silva, de que seus candidatos teriam sido atacados em sua integridade moral pela campanha da adversária e candidata à reeleição não se confirma. Apoiadores de Marina Silva, inclusive, atribuem à campanha do PT a responsabilidade por sua derrota em virtude de uma suposta intensa campanha negativa. A campanha do PT foi a que menos dialogou com seus adversários e, quando o fez, foi a que menos utilizou a estratégia de desconstrução da imagem pessoal deles. A campanha campeã na utilização dessa forma de diálogo, proporcionalmente, foi a da própria Marina Silva, seguida pela campanha de Aécio Neves, em proporção significativamente menor. A campanha de Dilma Rousseff apenas se igualou, proporcionalmente, à do PSDB na desconstrução da imagem de seus adversários nos spots durante o primeiro turno das eleições.

Veremos, em seguida, como evoluiu o uso do diálogo durante o segundo turno das eleições. Nesse caso, somente com as duas principais forças políticas em disputa: PT e PSDB.

\section{O segundo turno da eleição presidencial de 2014: como dialogaram PT e PSDB?}

\section{O HGPE em bloco (segundo turno)}

Assim como no primeiro turno, os programas televisivos em bloco do PSDB eram um pouco menos fragmentados do que os do PT, ou seja, suas peças eram mais longas. Uma das suas principais características era a utilização de um jingle longo, cantado por artistas apoiadores da campanha, entrecortado por depoimentos de apoio da classe artística. Ao todo, os programas do PSDB de segundo turno apresentaram 167 peças publicitárias, enquanto os do PT apresentaram 180 peças, relativamente independentes ${ }^{8}$.

No total, os programas de Aécio Neves fizeram 90 menções diretas à adversária, seu governo ou partido, enquanto os programas de Dilma Rousseff fizeram 72 menções diretas ao adversário, seu partido ou governos passados. Considerei os números muito expressivos diante da literatura internacional, que já chegou a afirmar a escassez de diálogo nas campanhas eleitorais contemporâneas. Calculamos a disposição dialógica de cada uma das candidaturas tomando como universo o número de peças apresentadas nas campanhas. O resultado é que, em 53,9\% das peças publicitárias da propaganda de segundo turno do PSDB, houve tentativa de diálogo com a adversária, somando-se as três

\footnotetext{
${ }^{8}$ Digo relativamente na medida em que toda propaganda eleitoral apresenta algumas divisões difusas entre as peças em função da abordagem contínua de uma mesma temática. São as diferenças visuais e comunicativas que vão determinar o momento de término de uma peça e o início de outra.
} 
categorias selecionadas para a análise: 1) desconstrução da imagem pessoal, 2) desconstrução da imagem política e 3) crítica ao projeto político defendido pelo adversário. No caso do PT, a tentativa de diálogo ocorreu em $40 \%$ de suas peças publicitárias, um número relativamente alto, considerando-se a usual baixa disposição de candidatos à reeleição para o diálogo. Ao comparar o que ocorreu durante o primeiro turno, nota-se uma mudança significativa na disposição para o diálogo em ambas as candidaturas. Enquanto o PSDB aumentou as menções à adversária em mais de $40 \%$ entre o primeiro e o segundo turno da campanha, o PT aumentou esse percentual em quase $36 \%$.

\section{Gráfico 6 \\ Evolução do diálogo direto entre candidaturas do primeiro para o segundo turno (\%)}

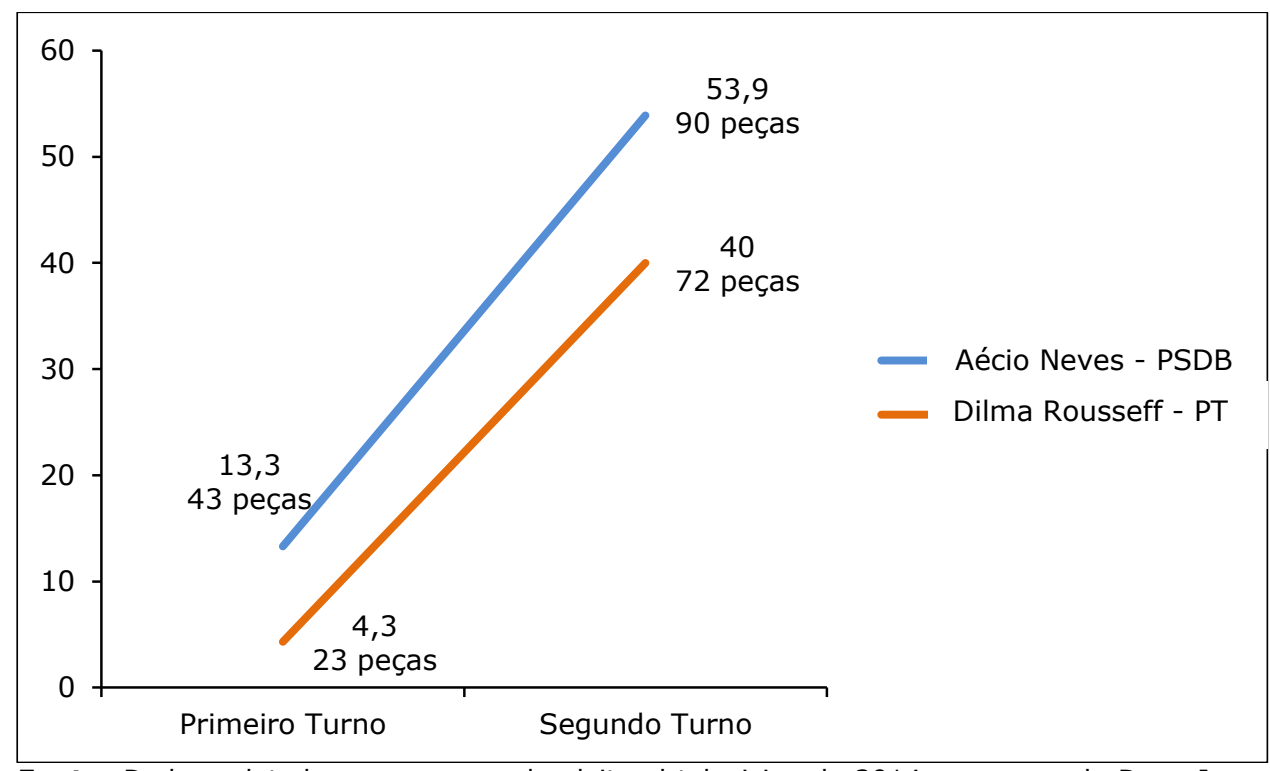

Fonte: Dados coletados na propaganda eleitoral televisiva de 2014 no acervo do Doxa-Iesp. Classificação própria.

Esse fenômeno, provavelmente, deveu-se ao aumento súbito da competitividade da campanha quando, já no início do segundo turno, pesquisas de opinião indicaram a virtual vitória do candidato de oposição. As pesquisas confirmaram esse resultado até a última semana da campanha, quando passaram a indicar a vitória da candidata à reeleição. Conforme indicado na literatura, quanto maior a competitividade da campanha, maior é a probabilidade da ocorrência de diálogo entre as candidaturas. O resultado, portanto, confirma algumas das expectativas da literatura acadêmica sobre diálogo em campanhas.

Mas que tipo de diálogo pode ser percebido na campanha de segundo turno? Qual foi a qualidade do diálogo entre as duas principais forças em disputa? Nesse caso, a segunda categoria foi a mais utilizada por ambas as candidaturas, o que significa que o principal objetivo de ambos ao mencionarem o adversário era desconstruir a imagem 
política dele, apontando falhas em sua capacidade governativa. Esse comportamento já havia sido observado na campanha do PSDB durante o primeiro turno, o que é comum em candidaturas desafiantes: questionar os resultados governamentais do candidato à reeleição. Mas na campanha do PT foi verificada uma alteração no padrão de diálogo: enquanto no primeiro turno predominou o terceiro tipo de diálogo, que aposta em uma comparação entre as propostas de campanha, no segundo turno o diálogo assumiu um tom muito mais agressivo com relação ao adversário, que, nesse momento, já ameaçava sua reeleição.

\section{Gráfico 7 \\ O uso dos tipos de diálogo pelas candidaturas no HGPE em bloco no segundo turno (\%)}

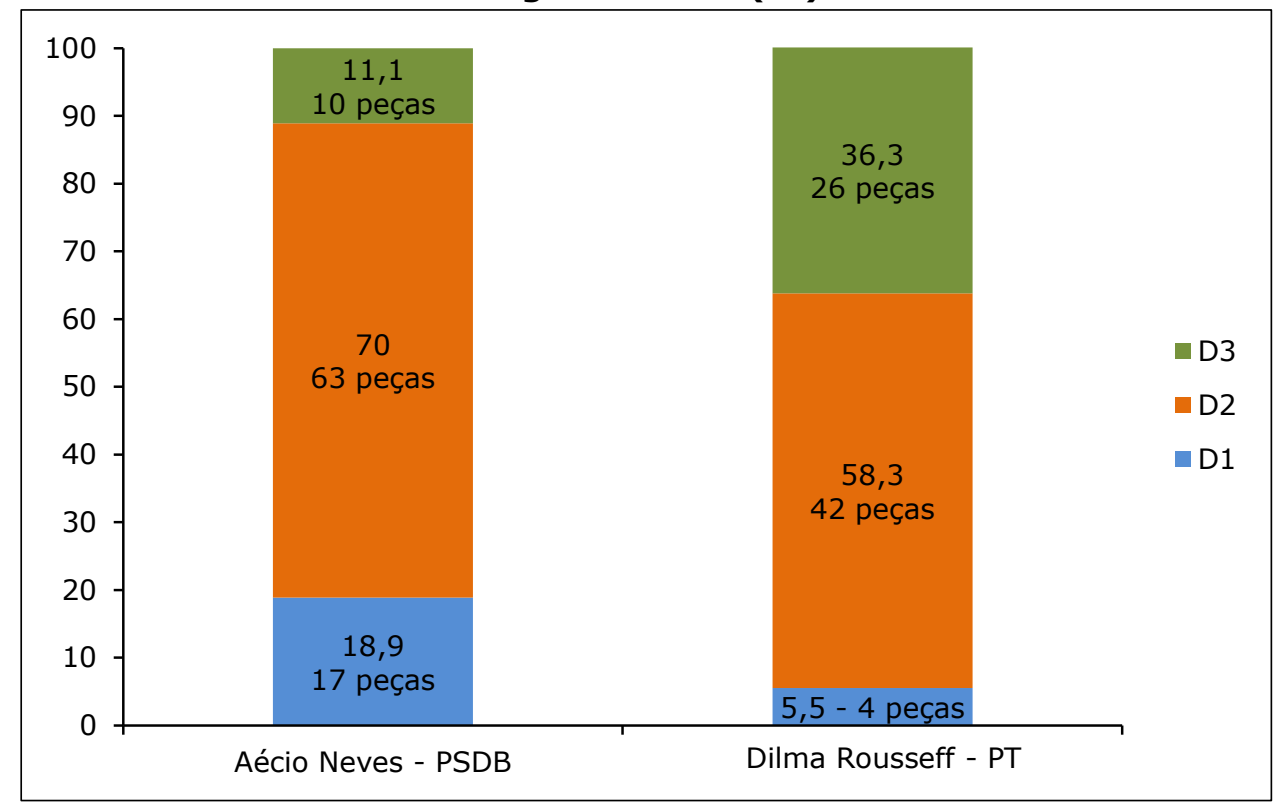

Fonte: Dados coletados na propaganda eleitoral televisiva de 2014 no acervo do Doxa-Iesp. Classificação própria.

Legenda: D1 = desconstrução da imagem pessoal do adversário; D2 = desconstrução da imagem política do adversário; D3 = crítica ao projeto político defendido pelo adversário.

Entretanto, quando a campanha do PT utilizava essa estratégia, referia-se a governos do PSDB em geral e ao governo de Minas Gerais, especificamente durante a gestão do adversário Aécio Neves. De fato, o uso da segunda estratégia foi relativamente mais importante para o PSDB do que para o PT: $70 \%$ das tentativas de diálogo do PSDB eram fruto dessa segunda categoria, enquanto para o PT isso ocorreu em $58,25 \%$ das vezes em que dialogou. No caso do PSDB, houve um aumento proporcional pouco expressivo no uso da segunda estratégia entre o primeiro e o segundo turno. Já para o PT, o uso dessa estratégia no segundo turno dobrou com relação ao primeiro. 
Seguem abaixo dois exemplos do uso pelas candidaturas dessa segunda estratégia:

O seu governo chega ao final, a meu ver, de forma melancólica. A grande verdade é essa, porque fracassou na condução da economia, inflação alta, crescimento baixo, fracassou na melhoria dos nossos indicadores sociais. E nós estamos aí com essas denúncias de corrupção que assustam e trazem indignação a todos os brasileiros (programa eleitoral do PSDB, em 15/10/2014, reproduzindo imagens do debate na Bandeirantes - fala de Aécio Neves).

Eu pedi essa reflexão a vocês pra alertar que aqueles mesmos que diziam que era impossível nascer um novo Brasil, esse novo Brasil que todos vocês ajudaram a construir, são os mesmos que tentam voltar agora e dizem que têm um remédio para todos os males do Brasil. Podem estar certos que qualquer remédio deles tem o gosto amargo do desemprego, do arrocho salarial e da falta de oportunidades (programa eleitoral do PT, dia 16/10/2014, sexta peça - fala de Lula).

Foi na utilização das outras duas estratégias que as candidaturas mais se diferenciaram. A campanha de Aécio Neves promoveu, em segundo lugar, a primeira estratégia, ou seja, a da desconstrução da imagem pessoal da adversária, que caracterizou $18,9 \%$ das suas formas de diálogo. Essa foi a terceira estratégia utilizada pela campanha do PT, com uma incidência de apenas 5,5\% do conjunto dialógico apresentado. Tal fato contraria definitivamente a tese amplamente difundida pela candidatura do PSDB e por alguns setores da mídia de que a candidatura do PT se especializou em destruir reputações, especialmente do ponto de vista pessoal. Teria feito isso primeiro com Marina Silva, depois com Aécio Neves. Na propaganda do dia 22/10/2014 da campanha do PSDB, o candidato Aécio proferiu o seguinte discurso:

Essa eleição vai ficar marcada pela mentira, pela calúnia dos meus adversários, pela covardia. Segundo levantamento de um importante jornal nacional, nesse segundo turno, de 22 peças publicitárias produzidas pela campanha da minha adversária, 19 foram pra me atacar e apenas três para falar de $\operatorname{propostas}^{9}(\ldots)$. Em uma covarde onda de falsidades e calúnias, tentam jogar na lama o nome honrado da minha família. Tentam jogar na lama o meu nome honrado, construído em uma vida pública de mais de 30 anos de dedicação a Minas e ao Brasil. (...) A campanha adversária tenta me desqualificar do ponto de vista pessoal de todas as formas (programa eleitoral do PSDB, dia 22/10/2014, segunda peça - fala de Aécio Neves).

\footnotetext{
${ }^{9}$ Convido qualquer pesquisador a comprovar esses dados. Eles absolutamente não correspondem à verdade.
} 
Ao mesmo tempo em que acusa a candidatura adversária de ataques pessoais, usa contra ela os termos: mentira, covardia, covarde, falsidades, calúnias. Todos eles atributos pessoais em vez de políticos. Ou seja, acusou a adversária daquilo que fazia no próprio discurso: desconstrução da imagem pessoal. Ao longo de toda a campanha televisiva do segundo turno, o PSDB investiu $10,2 \%$ de suas peças na desconstrução da imagem pessoal de sua adversária, enquanto apenas $2,2 \%$ das peças do PT continham esse tipo de mensagem ${ }^{10}$.

Seguem abaixo dois exemplos da utilização desse tipo de recurso dialógico, elaborado pelas candidaturas de PSDB e PT:

Com medo de perder o poder, Dilma e o PT estão fazendo a campanha mais baixa, agressiva e mentirosa de toda a história recente democrática do Brasil. (...) Atacam e mentem sobre Aécio e o seu trabalho em Minas Gerais para tentar manchar a história do político competente e honrado que ele é. Mas, para Dilma e o PT, tudo isso parece não bastar. Não agridem apenas Aécio Neves. Eles também agridem, de forma covarde, o filho, o pai, o marido, o irmão, o cidadão Aécio Neves (programa eleitoral do PSDB, dia 15/10/2014, segunda peça - fala do apresentador).

O comportamento dele não é o comportamento de um candidato, de alguém que tem responsabilidade. É o comportamento de um filhinho de papai (programa eleitoral do PT, dia 20/10/2014, oitava peça - discurso de Lula em palanque).

A campanha de Dilma Rousseff optou por utilizar a terceira categoria dialógica como segundo recurso preferencial: $36,25 \%$ de suas estratégias dialógicas visavam atacar o projeto político defendido pelo adversário. Na campanha de Aécio Neves, por sua vez, esse recurso correspondeu a $11,1 \%$ de suas estratégias dialógicas. No conjunto total da campanha de segundo turno, ou seja, não apenas no universo de peças destinadas ao diálogo, mas na soma geral das peças, o PT destinou $14,5 \%$ de suas peças para criticar o projeto político do adversário e apresentar sua proposta, enquanto o PSDB o fez em $6 \%$ de suas peças.

Seguem abaixo dois exemplos da utilização da terceira categoria dialógica nas candidaturas:

A impressão que eu tenho é que temos dois candidatos de oposição. Seu partido governou 12 anos o Brasil, candidata. A senhora está há 4 anos no governo, por que não fez isso? Por que não assumiu a responsabilidade, por exemplo, de pelo menos executar o orçamento da área de segurança pública?

\footnotetext{
10 Note-se que esses percentuais não se referem ao uso do primeiro diálogo no conjunto de diálogos, mas ao uso do referido diálogo no conjunto de peças, ou seja, no total da campanha, razão pela qual os percentuais diferem daqueles apresentados no Gráfico 7.
} 
O Fundo Nacional de Segurança foi executado em menos de $40 \%$. O Fundo Penitenciário, muito menos do que isso. (...) Eu quero dizer a você, telespectador, que no meu governo eu vou assumir o comando de uma política nacional de segurança pública: controlando nossas fronteiras, fortalecendo as nossas Forças Armadas, também abandonadas no seu governo. Dando também à Polícia Federal a estrutura que ela deixou de ter; ela tem o pior orçamento de investimento dos últimos cinco anos (programa eleitoral do PSDB, dia 15/10/2014, reproduzindo imagens do debate na Bandeirantes).

Portanto é muito difícil não se indignar quando meu adversário fala em "medidas impopulares". Ora, se são impopulares é porque são contra o povo e eu tenho um lado muito claro: o lado do povo. O Brasil não pode voltar àquele passado em que era governado por uma elite e para uma elite. Pois é contra esse retrocesso que vou lutar com todas as minhas forças (programa eleitoral do PT, dia 13/10/2014, quarta peça - fala de Dilma Rousseff).

HGPE em spots de campanha no segundo turno

Foram analisados 84 spots da campanha presidencial do segundo turno de 2014: 36 do PSDB e 48 do PT.

\section{Gráfico 8}
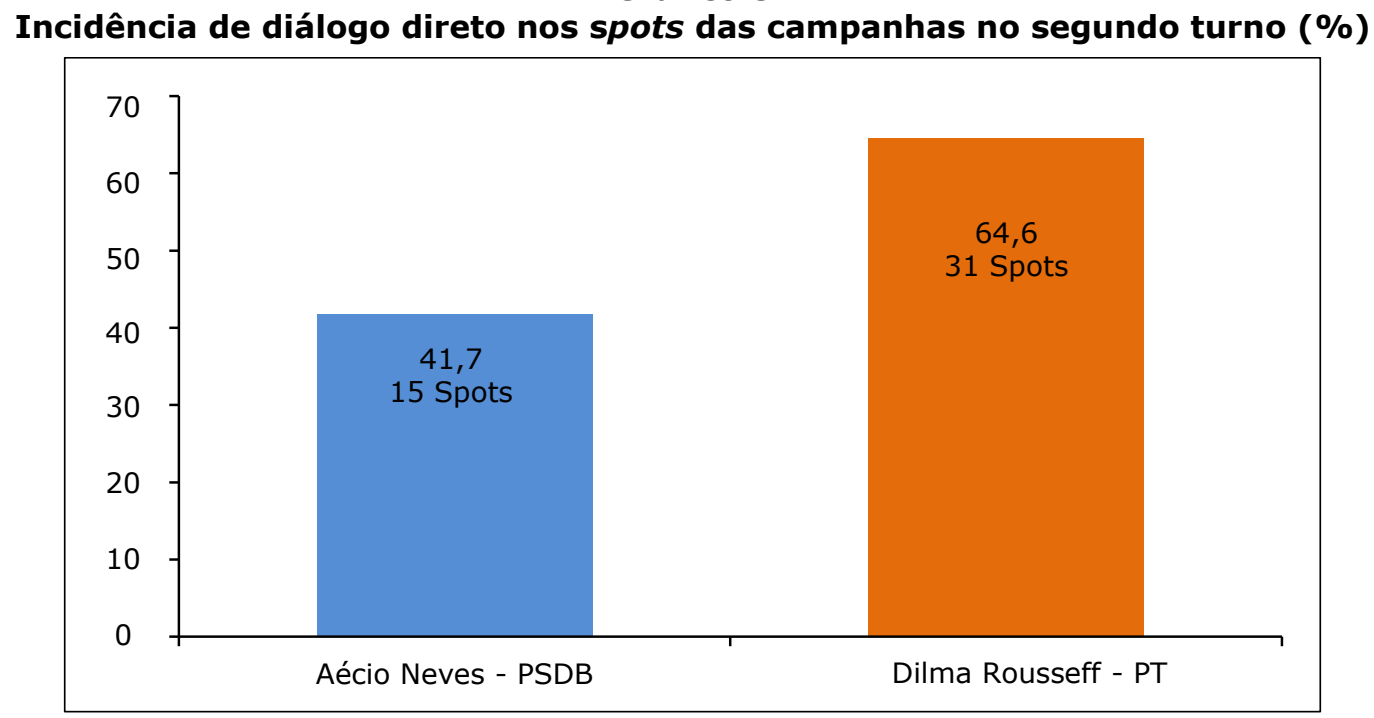

Fonte: Dados coletados na propaganda eleitoral televisiva de 2014 no acervo do Doxa- Iesp. Classificação própria.

O aumento do diálogo na campanha de segundo turno ganhou um destaque ainda maior na análise dos spots. Pela primeira vez, foi a campanha da candidata do PT que 
buscou maior diálogo com seu adversário: em 64,6\% dos spots verificou-se alguma menção direta ao seu adversário do PSDB, que, por sua vez, o fez em $41,7 \%$ de seus spots de segundo turno.

Proporcionalmente, durante os spots, o PT contribuiu com cerca de $55 \%$ das estratégias dialógicas da campanha do segundo turno. O PSDB contribuiu com $39 \%$ desse percentual. Pela primeira vez, o comportamento das candidaturas em campanha contrariou o padrão demonstrado na literatura, tendo a candidata à reeleição apresentado uma maior disposição para o diálogo. Como mencionado acima, o que explica esse fenômeno é, provavelmente, o aumento da competitividade da campanha e uma real ameaça de derrota eleitoral para o PT, segundo pesquisas de intenção de voto. Porém, importa ainda fazer uma análise qualitativa, ou seja, que tipo de diálogo buscou cada uma das candidaturas.

\section{Gráfico 9 \\ O uso dos tipos de diálogo pelas candidaturas nos spots no segundo turno (\%)}

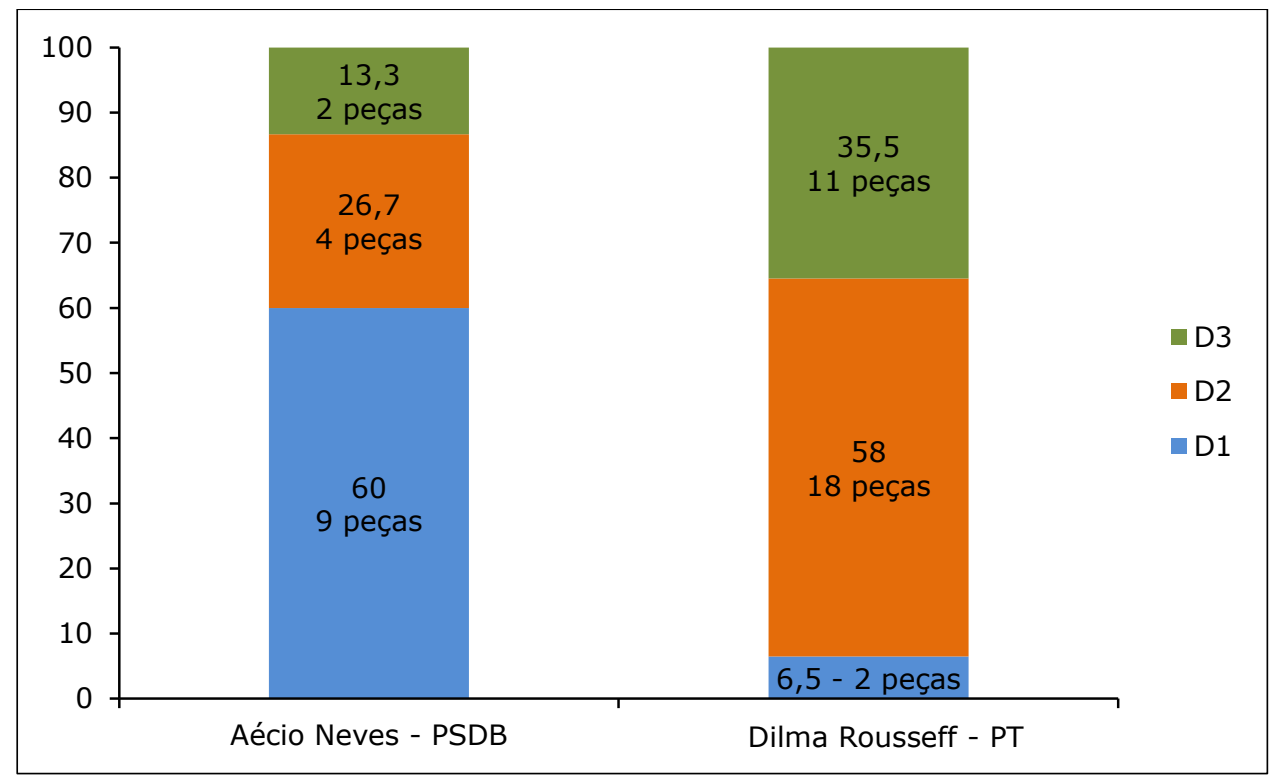

Fonte: Dados coletados na propaganda eleitoral televisiva de 2014 no acervo do Doxa-Iesp. Classificação própria.

Legenda: $\mathrm{D} 1$ = desconstrução da imagem pessoal do adversário; D2 = desconstrução da imagem política do adversário; D3 = crítica ao projeto político defendido pelo adversário.

Se a quantidade de diálogo em spots do PSDB foi menor do que a do PT, sua virulência foi muito maior. Em $60 \%$ das menções diretas à sua adversária, a campanha de Aécio Neves buscou desconstruir a imagem pessoal de Dilma Rousseff. Esta o fez contra Aécio em apenas $6,5 \%$ de seus intentos de diálogo. A principal estratégia da candidatura do PT foi a desconstrução da imagem política de seu adversário $(58,1 \%)$, fazendo críticas ao seu partido quando esteve no governo federal ou ao seu próprio governo no estado de Minas Gerais. Nesse último caso, ficou na memória o reiterado bordão "quem conhece 
Aécio, não vota no Aécio", em referência à sua derrota eleitoral no primeiro turno em Minas Gerais, estado que governou por dois mandatos. O terceiro tipo de diálogo, que contribuiria para um maior esclarecimento do eleitor, foi a segunda estratégia dialógica mais utilizada em spots do PT e foi a terceira do PSDB.

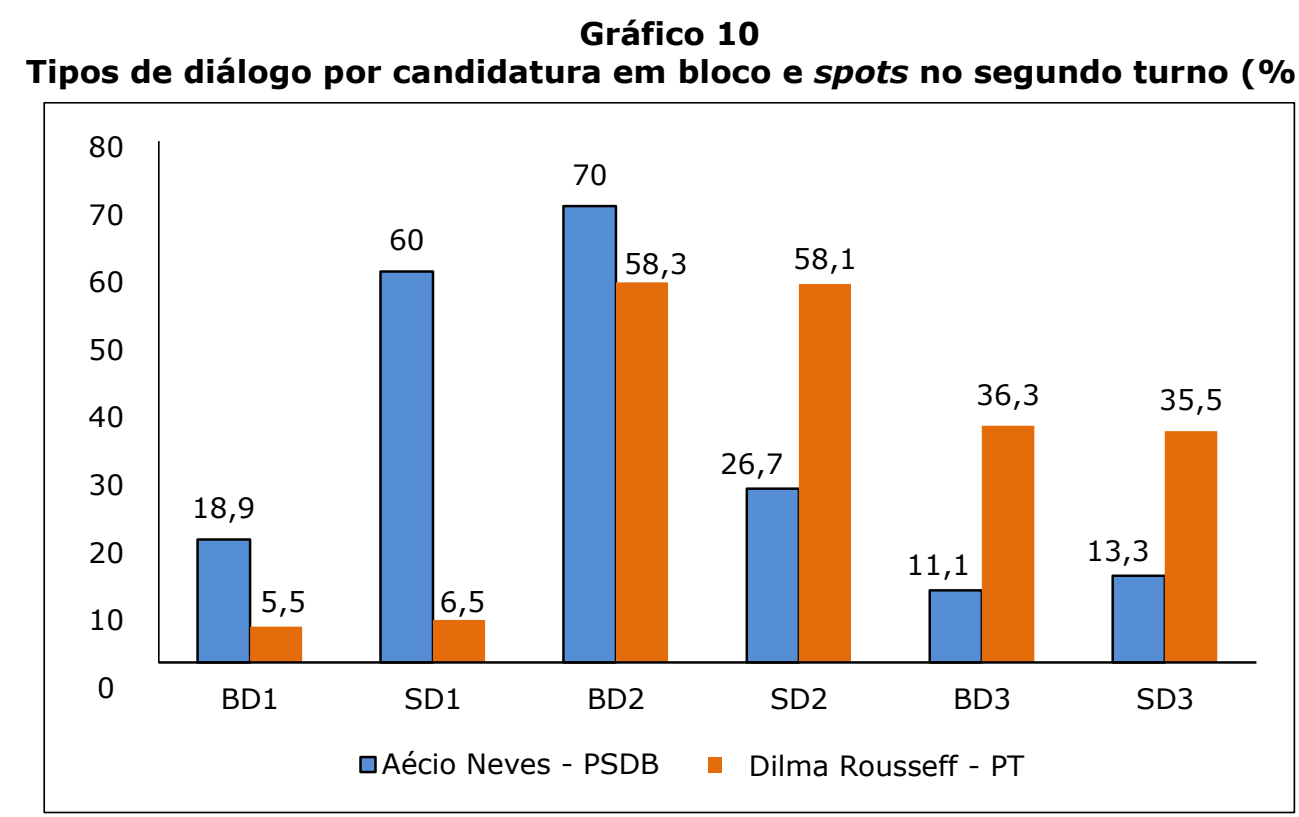

Fonte: Dados coletados na propaganda eleitoral televisiva de 2014 no acervo do Doxa-Iesp. Classificação própria.

Legenda: $\mathrm{BD} 1$ = diálogo tipo 1 em bloco; $\mathrm{BD} 2=$ diálogo tipo 2 em bloco; $\mathrm{BD} 3=$ diálogo tipo 3 em bloco; SD1 = diálogo tipo 1 em spots; SD2 = diálogo tipo 2 em spots; SD3 = diálogo tipo 3 em spots.

A regularidade no padrão de uso das estratégias de diálogo do PSDB em bloco e spots durante o primeiro turno da campanha não se repetiu no segundo turno. Neste, ficou patente que a virulência da campanha negativa, traduzida pela desconstrução da imagem pessoal da adversária, foi canalizada para os spots, em que o segundo tipo de diálogo declinou na mesma proporção do uso da estratégia D2. É possível afirmar, portanto, que, enquanto a campanha do PSDB utilizou a desconstrução da imagem política da adversária nos programas do HGPE em bloco, os spots foram utilizados para desconstruir sua imagem pessoal. O terceiro tipo de diálogo foi igualmente inexpressivo em um e outro cenário comunicacional.

Da mesma forma, a irregularidade da campanha do PT no primeiro turno não se repetiu no segundo. Impressiona a equivalência percentual no uso de cada estratégia nos distintos segmentos da propaganda política televisiva. Parecia que a propaganda em spots era uma réplica síntese da propaganda em bloco, ao menos em termos de diálogo em campanha. 
Um fato curioso chama a atenção: tanto Aécio Neves no primeiro turno quanto Dilma Rousseff no segundo estiveram muito próximos, segundo as pesquisas de intenção de voto, de uma derrota. O primeiro para Marina Silva, a segunda para o próprio Aécio Neves, e viraram o resultado na reta final. Simultaneamente, tanto Aécio no primeiro turno quanto Dilma no segundo turno adotaram um padrão comunicacional regular nos diferentes estilos de propaganda na televisão, ao menos no que concerne aos seus comportamentos diante dos adversários. Padrões comunicacionais regulares contribuem positivamente para o sucesso eleitoral? Essa pode ser uma interessante agenda de pesquisa a ser investigada em estudos de recepção. Aqui trabalhamos exclusivamente com a emissão de discursos de campanha.

\section{Conclusão}

Neste artigo meu objetivo foi mobilizar a categoria do "diálogo" para analisar a campanha presidencial de 2014. Conforme visto na revisão da literatura, feita no segmento do artigo "Diálogo em campanhas eleitorais: breve revisão da literatura recente", o diálogo é visto por seus investigadores como um critério qualificador da democracia na medida em que permite ao eleitor um maior contraste entre as propostas apresentadas pelas candidaturas em disputa. Utilizando a perspectiva da racionalidade do voto, quanto maior a informação e a comparabilidade entre candidatos, maior é a possibilidade de o eleitorado votar conforme suas expectativas e preferências.

Segundo esses autores, o diálogo ocorre em uma campanha eleitoral quando uma candidatura se refere direta ou indiretamente ao seu adversário e/ou respectivos partido, governo ou propostas. Neste artigo, trabalhei exclusivamente com o diálogo direto, ou seja, quando os adversários eram mencionados explicitamente na propaganda eleitoral de alguma candidatura.

Tal literatura sustenta que o ambiente informacional de uma campanha é dominado pelos dois maiores partidos em disputa, sendo considerada insignificante a comunicação da terceira força eleitoral. Não foi o que ocorreu no processo eleitoral de 2014. A entrada de Marina Silva (PSB) na disputa e sua ascensão na intenção de votos, retirando virtualmente do segundo turno a segunda força mais importante (Aécio Neves, PSDB) ${ }^{11}$, levou à escolha de estudar a comunicação entre os três primeiros colocados no primeiro turno. A pesquisa avançou pelo segundo turno da eleição com as duas candidaturas que restaram. Assumo aqui a perspectiva de que primeiro e segundo turnos são duas eleições diferentes e, portanto, foram analisadas em segmentos diferentes do artigo, embora o contexto geral das campanhas tenha permanecido o mesmo.

A primeira dimensão analítica do artigo foi quantitativa, o que significa dizer que o propósito inicial foi quantificar o uso da estratégia do diálogo em cada candidatura. Nesse

11 Não se confirmando na prática, entretanto. 
aspecto, a literatura internacional sobre diálogo em campanhas afirma que candidaturas desafiantes apresentam maior propensão ao diálogo, ou seja, preocupam-se mais em trazer o adversário para sua campanha. Já candidatos à reeleição tenderiam a evitar tanto responder a seus adversários quanto provocá-los em intentos de diálogo, preferindo ignorá-los. Entretanto, essa mesma literatura, em geral, registra a escassez de diálogo nas campanhas eleitorais, fenômeno com maior tendência de ser revertido quanto maior a competitividade da disputa.

A eleição presidencial de 2014 foi particularmente competitiva, observando distintos cenários de resultados, sugeridos por pesquisas de intenção de voto, tanto no primeiro quanto no segundo turno. Na largada do primeiro turno, os candidatos favoritos a passar para o segundo turno eram Dilma Rousseff (PT) e Aécio Neves (PSDB). Entretanto, ao longo da campanha, as pesquisas de opinião sugeriam que, em um possível segundo turno entre a candidata à reeleição e um de seus adversários, Marina Silva (PSB) teria mais chances de vencer a eleição do que Aécio Neves (PSDB). A partir desse momento, a candidata do PSB passou a subir nas pesquisas, enquanto o candidato do PSDB declinava em proporções praticamente idênticas. Ao final da campanha, o cenário se inverteu novamente e Aécio Neves passou para o segundo turno juntamente com Dilma Rousseff, que manteve relativa estabilidade em sua intenção de voto ao longo do primeiro turno. Apoiado pela adversária derrotada do PSB, o candidato do PSDB permaneceu em vantagem com relação à adversária do PT durante quase toda a campanha de segundo turno, cenário revertido na reta final, resultando na reeleição de Dilma Rousseff.

A competitividade da campanha presidencial de 2014 foi acompanhada por um turbulento debate público, envolvendo as redes sociais da internet, dividindo o eleitorado em correntes ideológicas, mais fundamentalmente em petistas e antipetistas, ou seja, defensores da continuidade de um lado e da ruptura governamental de outro. Provavelmente ${ }^{12}$, a competitividade da campanha e a intensidade do debate público foram responsáveis por uma forte disposição para o debate entre as candidaturas disponíveis.

Durante o primeiro turno da campanha presidencial, os partidos que mais dialogaram foram os desafiantes, PSB e PSDB, correspondendo às expectativas da literatura pertinente. Entretanto, cada um deles optou por modelos distintos de propaganda para investir mais no diálogo com os adversários. Enquanto Marina Silva dominou $69 \%$ das estratégias de diálogo em programas em bloco, Aécio Neves respondeu por $23 \%$ do diálogo nesse formato de campanha. Já nos spots foi a candidatura do PSDB que dominou a estratégia de diálogo, com 55\%, enquanto a candidata do PSB respondeu por 35\%. Dilma Rousseff foi a candidata que menos procurou o diálogo com seus adversários durante o primeiro turno, correspondendo a 7\% do total de diálogo em blocos e $9 \%$ nos spots. O comportamento dos candidatos corrobora a expectativa da literatura, conforme já mencionado. A oscilação das preferências eleitorais se deu entre os candidatos

12 Digo provavelmente porque seria necessária a comparação com os mesmos dados em outras eleições de modo a confirmar a extraordinariedade do comportamento dialógico das candidaturas em 2014. 
do PSDB e do PSB, e foram estes também os que mais dialogaram. A estabilidade das preferências eleitorais do PT durante o primeiro turno converge para seu comportamento menos dialógico. Sendo este artigo um estudo de emissão, o que se quer explicar é o comportamento das elites e não dos eleitores. Portanto, não pretendo aqui explicar a variação no comportamento dos eleitores em função das estratégias de campanha, e sim o contrário ${ }^{13}$.

No segundo turno, o comportamento da campanha do PT modificou radicalmente diante de uma possível derrota, já que desde a primeira semana da campanha Aécio Neves figurava como virtual vencedor da eleição. Na propaganda em bloco, o candidato do PSDB foi responsável por $57 \%$ do diálogo em campanha contra $43 \%$ da candidata do PT, percentual muito elevado para candidatos à reeleição. Nos spots, a situação se inverteu: Dilma Rousseff dialogou bem mais do que seu adversário, respondendo por $61 \%$ das estratégias dialógicas de campanha contra 39\% de Aécio Neves. Certamente, a vantagem do PSDB nas pesquisas de intenção de voto contribuiu para a alteração no comportamento das candidaturas, ao menos do ponto de vista da quantidade de diálogos.

Na prática, o diálogo em campanhas eleitorais em geral, e especialmente no Brasil, se confunde com a propaganda negativa. É razoável supor que candidaturas que visem a adesão popular através do voto não irão mencionar diretamente seus adversários a fim de destacar seus atributos mais favoráveis. Pelo contrário, ao provocar o adversário sobre determinado tema de campanha, cada candidatura pretende demonstrar aos eleitores sua própria superioridade para lidar com o tema. Entretanto, há distintas maneiras de fazê-lo. Neste artigo, desenvolvi três categorias de diálogo, levando em consideração os padrões de diálogo direto identificados ao longo das campanhas eleitorais no Brasil: 1) desconstrução da imagem pessoal do adversário, 2) desconstrução da imagem política do adversário e 3) crítica ao projeto político defendido pelo adversário. Através da classificação nessas categorias procurei qualificar o diálogo empreendido pelas candidaturas.

Durante o primeiro turno da eleição presidencial, o tipo mais acionado de diálogo pelas candidaturas desafiantes foi o segundo: desconstrução da imagem política do adversário. Cerca de $60 \%$ do diálogo empreendido por PSB e PSDB visou esse objetivo, tanto na propaganda em bloco quanto nos spots. O comportamento dessas candidaturas foi coerente com seu papel na disputa. Não tendo a vantagem de apoiar-se em resultados de políticas públicas, os adversários buscam evidenciar fragilidades governamentais do candidato à reeleição.

Já a candidata do PT, quando dialogou com seus adversários, buscou principalmente contrastar propostas de campanha, criticando o projeto político do adversário. Mais de 70\% de seus intentos de diálogo na propaganda em bloco e mais de

\footnotetext{
13 Um interessante estudo de recepção da propaganda negativa na campanha eleitoral de 2014 foi realizado por Borba, Veiga e Martins (2015).
} 
$60 \%$ nos spots foram nesse sentido. Tal atitude também foi coerente com a postura de candidato à reeleição, na medida em que buscava demonstrar que seria mais seguro para os eleitores incrementar políticas públicas do que substituí-las por outras.

Quanto à primeira forma de diálogo, que configura a essência da propaganda negativa na medida em que busca desqualificar o adversário moralmente, foi a menos utilizada. Entretanto, foi possível identificá-la em cerca de $40 \%$ da propaganda do PSB e $20 \%$ da do PSDB, tanto na propaganda em blocos quanto nos spots. A campanha do PT só a utilizou durante o primeiro turno, em $20 \%$ dos spots. A campanha que mais atacou foi a de Marina Silva, contrariando todo um discurso de vitimização que se construiu em torno dela, atribuindo sua derrota a uma eficiente campanha negativa, supostamente empreendida pela candidatura do PT. Se propaganda negativa fosse suficiente para ganhar eleição, a candidata do PSB certamente teria sido eleita em $2014^{14}$.

O segundo turno da eleição presidencial de 2014 no Brasil demonstrou forte disposição para o debate entre as candidaturas disponíveis, dado o acirramento da disputa tanto em intenção de votos quanto no debate público. Fato é que identificamos a ocorrência de diálogo direto e indireto - embora esse último não tenha entrado na contabilidade deste artigo - , convergência temática e tentativas de subversão da propriedade temática do adversário, todos indicativos de um comportamento altamente dialógico das candidaturas. Supostamente, tudo isso contribuiria para a qualidade da democracia em seu aspecto estritamente eleitoral.

Entretanto, quando observamos o tipo de diálogo que se estabeleceu, torna-se necessário fazer algumas ressalvas. A maioria absoluta das inserções dialógicas na propaganda em bloco de ambos os partidos se enquadrava na categoria 2: desconstrução da imagem política do adversário (70\% das inserções dialógicas do PSDB e $58 \%$ das do PT). Nos spots, o percentual desse tipo de diálogo permaneceu inalterado na campanha do $\mathrm{PT}$, reduzindo-se drasticamente para cerca de $27 \%$ em relação à campanha em bloco do PSDB. Conforme analisado acima, esse recurso não favorece o contraponto entre propostas, deixando ao adversário a decisão de responder ou não a uma afirmação ou acusação. Em geral, as candidaturas não perdem seu tempo na televisão para discutir assuntos que foram postos na pauta de forma negativa pelo seu adversário. Fazendo isso, assumem o risco de que o eleitorado concorde com a conclusão negativa de seu opositor. Mesmo assim, sempre cabe ao eleitor a decisão final de acreditar em uma ou outra versão e, finalmente, decidir o seu voto. Certamente, essa é a estratégia dialógica que apresenta o menor grau de risco de perdas para os candidatos, razão pela qual foi a mais utilizada na campanha de um modo geral.

A terceira categoria foi utilizada de forma relativamente importante pela campanha do PT, mas de forma marginal pela campanha do PSDB (em média 36\% das inserções dialógicas do primeiro e $12 \%$ das do segundo turno, tanto na propaganda em blocos quanto

\footnotetext{
${ }^{14}$ Como dito anteriormente, este artigo não é um estudo de recepção e, portanto, não se presta à explicação
} do comportamento eleitoral e sim das escolhas comunicativas das elites políticas. 
nos spots). A campanha do PT esforçou-se por contrastar seu próprio modo de governar com o de seu oponente. Certamente, não o fez de maneira técnica e sim política. Isso significa dizer que falou dos aspectos positivos de seu governo e dos negativos dos governos dos adversários. O PSDB poderia ter feito o mesmo, mas a estratégia 3 não foi a sua preferida. Utilizou um recurso inovador, embora já estivesse presente na campanha de José Serra em 2010, que foi o de tentar quebrar a propriedade temática do PT na área social, desqualificando seu principal programa de redistribuição de renda, o Bolsa Família, ao considerá-lo simples fusão de diversos programas sociais do governo de Fernando Henrique Cardoso.

Finalmente, a primeira estratégia é a menos política, porque trabalha no plano da ofensa pessoal, desqualifica o adversário moralmente e o trata com soberba e superioridade. Aécio Neves (PSDB) e sua campanha declararam inúmeras vezes que o candidato estava sendo ofendido em sua honra pela campanha adversária. Nesse diagnóstico, foram apoiados por setores da grande mídia que atribuíram a derrota de Marina Silva (PSB) aos ataques do PT e depois, no segundo turno, referendaram a fala de Aécio Neves afirmando que, naquele momento, a campanha do PT fazia o mesmo com ele. Surpreendentemente, a análise de dados demonstrou o contrário: o PSDB fez ataques pessoais em $19 \%$ de suas estratégias dialógicas no HGPE em bloco, enquanto o PT utilizou esse recurso em $6 \%$ delas. Nos spots, a campanha negativa contra a adversária do PSDB subiu a patamares expressivos: 60\%. Obviamente meus dados trabalham com informações oficiais da campanha, de forma mais precisa, exclusivamente com o Horário Gratuito de Propaganda Eleitoral (HGPE). O que ocorre na campanha extraoficial, especialmente nas redes sociais, não é responsabilidade de nenhuma das duas campanhas oficiais. Mesmo os sites oficiais das candidaturas não foram objeto de análise neste artigo. Mas foi em um debate ao vivo na TV Bandeirantes, trecho não reproduzido no HGPE, que o próprio candidato do PSDB chamou a candidata do PT de leviana e mentirosa.

A título de finalização dessa análise, cumpre retomar a premissa utilizada no início deste artigo: o diálogo em campanha teria um caráter virtuoso na democracia, já que seria útil no esclarecimento do eleitor para a decisão eleitoral. O uso de estratégias de desqualificação dos adversários, próprio de um tipo de campanha negativa, não é novidade no contexto das campanhas eleitorais brasileiras. Sua intensificação, sim. A extrapolação de condições mínimas de respeito entre candidaturas choca o observador mais atento. Em termos analíticos, é desafiador pensar que justamente o diálogo, entendido pela literatura de referência como um elemento qualificador da democracia, apareça como instrumento de depreciação da própria democracia ao desprezar o eleitor em sua capacidade de decidir o voto.

O acirramento da disputa entre PT e PSDB durante a campanha eleitoral de 2014, com a participação coadjuvante de Marina Silva, foi agravado pela divisão ideológica da sociedade e por uma crescente intolerância política, e atingiu o seu ápice durante o processo de impeachment da presidente Dilma Rousseff, que resultou no seu afastamento 
definitivo do governo em 2016. Michel Temer (PMDB), vice-presidente eleito, assumiu o governo com uma agenda política neoliberal de contenção do gasto público e reformas políticas impopulares - como a trabalhista e a da previdência. A agenda do governo aprovada nas urnas, portanto, foi substituída pela do partido derrotado, o PSDB, que se tornou o principal aliado do governo Temer. Nas eleições de 2018, a imensa impopularidade do governo federal derrotou as candidaturas do PMDB e do PSDB, reduzindo o poder de influência desses dois partidos nas esferas legislativas federal e estaduais. O PT manteve seu poder de influência em governos estaduais, ampliou o tamanho de suas bancadas legislativas na maioria dos estados e elegeu a maior bancada na Câmara Federal, apesar de sua principal liderança, o ex-presidente Luiz Inácio Lula da Silva, ter sido condenado e preso por crimes relacionados à corrupção. O partido terminou a campanha presidencial de 2018 em segundo lugar em uma disputa acirrada com um candidato de um partido até então desconhecido e inexpressivo, o PSL, que, a partir de 2019, passou a comandar o país como sua principal força política. A campanha de 2018, portanto, interrompeu a polarização entre PT e PSDB nas disputas presidenciais brasileiras.

\section{Referências bibliográficas}

Borba, F. M.; VeigA, L. F.; MARTins, F. B. "Propaganda negativa na campanha presidencial em 2014. Ou como tudo que é frágil se desmancha no ar". Revista de Estudos Políticos, vol. 6, no 1, 2015.

BRUGNAGO, F.; CHAIA, V. "A nova polarização política nas eleições de 2014: radicalização ideológica da direita no mundo contemporâneo do Facebook". Aurora: Revista de Arte, Mídia e Política. São Paulo, vol. 7, no 21, p. 99-129, out. 2014-jan. 2015.

BUDGE, I.; FARLIE, D. J. Explaining and predicting elections: issue effects and party strategies in twenty-three democracies. London: Allen \& Unwin, 1983.

Downs, A. An economic theory of democracy. New York: Harper and Row, 1957.

KAPLAN, N.; PARK, D. K.; RIDOUT, T. N. "Dialogue in American political campaigns? An examination of issue convergence in candidate television advertising". American Journal of Political Science, vol. 50, no 3, 2006.

McComBS, M.; SHAW, D. "The agenda-setting function of mass media". Public Opinion Quarterly, New York, vol. 36, no 2, p. 176-187, 1972.

PAGE, B. Choices and echoes in presidential elections. Chicago: University of Chicago Press, 1978.

Petrocik, J. R. "Issue ownership in presidential elections, with a 1980 case study". American Journal of Political Science, vol. 40, no 3, p. 825-850, 1996.

Petrocik, J. R.; Benoit, W. L.; HANSEN, G. J. "Issue ownership and presidential campaigning, 19522000". Political Science Quarterly, vol. 118, no 4, p. 599-626, 2003.

SigelmAN, L.; BUELL JR., E. H. "Avoidance or engagement? Issue convergence in U.S. presidential campaigns (1960-2000)". American Journal of Political Science, vol. 48, no 4, p. 650-661, 2004. 
Simon, A. F. The winning message: candidate behavior, campaign discourse, and democracy. New York: Cambridge University Press, 2002.

STOKES, D. E. "Spatial models of party competition". American Political Science Review, vol. 57, p. 368-377, 1963.

Walgrave, S.; LefeVere, J.; Nuytemans, M. "Issue ownership stability and change: how political parties claim and maintain issues through media appearances". Political Communication, vol. 26, no 2, p. 153-172, 2009.

Weber, M. H. Imagem pública. In: Rubim, A. A. C. (org.). Comunicação e política: conceitos e abordagens. Salvador: EDUFBA/Unesp, 2004.

Xenos, M. A.; Foot, K. A. "Politics as usual, or politics as unusual? Position taking and dialogue on campaign websites in the 2002 U.S. elections". Journal of Communication, vol. 55, no 1, p. 169-185, 2005.

\begin{abstract}
Dialogue in campaign: an analysis of the communicative strategies of confrontation in the Brazilian presidential election of 2014

This article intends to identify the dialogue, as well as its nature and contribution to the clarification of the electoral proposals, of the three main candidates competing in the 2014 presidential elections: Dilma Rousseff (PT), Aécio Neves (PSDB), and Marina Silva (PSB). The primary source of information was the Free Time of Electoral Advertising (block and spots) aired during the two rounds of the elections. The first objective was to elaborate a quantitative analysis of the occurrence of direct dialogue between the candidacies, identifying the candidates who had the most dialogue. The second objective was to qualify the nature of the dialogue undertaken by each candidacy, classifying it based on three categories: deconstruction of personal image; deconstruction of political image; criticism of the opponent's political project. Such classification will assess to what extent the dialogue between the candidates has allowed discerning with greater or lesser clarity the ideological-political contours between the governmental projects in dispute. It is concluded that the occurrence of dialogue between the candidates in 2014 was increased by the sudden rise in competitiveness of the campaign.
\end{abstract}

Keywords: electoral campaign; dialogue; democracy; elections

\title{
Resumen
}

Diálogo en campaña: un análisis de las estrategias comunicativas de confrontación en la elección presidencial brasileña de 2014

Este artículo pretende identificar la ocurrencia del diálogo, su naturaleza y contribución a la aclaración de las propuestas electorales de las tres principales candidaturas en disputa en las elecciones presidenciales de 2014: Dilma Rousseff (PT), Aécio Neves (PSDB) y Marina Silva (PSB). La principal fuente de información fue el programa Horário Gratuito de Propaganda Eleitoral (block and spots) conducido durante los dos turnos de las elecciones. El primer objetivo fue elaborar un análisis cuantitativo de la ocurrencia del diálogo directo entre las candidaturas. El segundo objetivo era calificar la naturaleza del diálogo que se emprendió por cada candidatura, clasificarla en tres categorías: deconstrucción de la imagen personal, deconstrucción de la imagen política, crítica al proyecto político defendido por el oponente. Esta clasificación nos permitió evaluar hasta qué punto el diálogo entre los candidatos permitía discernir sobre los contornos político-ideológicos de los proyectos gubernamentales en disputa con mayor o menor claridad. Se concluye que la aparición del diálogo entre los presidenciables en 2014 se vio potenciada por el repentino aumento de la competitividad de la campaña.

Palabras clave: campaña electoral; diálogo; democracia; elecciones 


\section{Résumé}

Dialogue dans la campagne: une analyse des stratégies communicatives de confrontation lors de l'élection présidentielle brésilienne de 2014

Cet article vise à identifier la présence du dialogue, sa nature et sa contribution à la clarification des propositions électorales des trois principaux candidats lors des élections présidentielles de 2014: Dilma Rousseff (PT), Aécio Neves (PSDB) et Marina Silva (PSB). La principale source d'information était l'émission Horário Gratuito de Propaganda Eleitoral Gratuita (bloc et spots) véhiculée pendant les deux tours des élections. Le premier objectif était d'élaborer une analyse quantitative de la présence d'un dialogue direct entre les candidats. Le second objectif était de qualifier la nature du dialogue qui a été entrepris par chaque candidat, en le classant en trois catégories: la déconstruction de l'image personnelle, la déconstruction de l'image politique, la critique du projet politique défendu par l'adversaire. Cette classification a permis d'évaluer dans quelle mesure le dialogue entre les candidats permettait de discerner plus ou moins clairement les contours politico-idéologiques des projets gouvernementaux en lice. On en conclut que l'apparition du dialogue entre les candidats à la présidence en 2014 a été concrétisée par l'augmentation soudaine de la compétitivité de la campagne. Mots-clés: campagne électorale; dialogue; démocratie; élections

Artigo ressubmetido à publicação em 23 de fevereiro de 2018. Artigo submetido à publicação em 26 de novembro de 2018.

Versão final aprovada em 4 de novembro de 2019.

Opinião Pública adota a licença Creative Commons CC-BY. 